\title{
Proliferation and Survival of Embryonic Sympathetic Neuroblasts by MYCN and Activated ALK Signaling
}

\author{
Marco Kramer, ${ }^{1,2,3}$ DDiogo Ribeiro, ${ }^{4}$ Marie Arsenian-Henriksson, ${ }^{4}$ Thomas Deller, ${ }^{2}$ and Hermann Rohrer ${ }^{1,2,3}$ \\ ${ }^{1}$ Max-Planck-Institute for Brain Research, Developmental Neurobiology, 60438 Frankfurt/Main, Germany, ${ }^{2}$ Institute of Clinical Neuroanatomy, Goethe \\ University Frankfurt/Main, 60590 Frankfurt/Main, Germany, ${ }^{3}$ Ernst-Strüngmann-Institute, 60528 Frankfurt/Main, Germany, and ${ }^{4}$ Department of \\ Microbiology, Tumor and Cell Biology, Karolinska Institutet, SE-17177 Stockholm, Sweden
}

Neuroblastoma (NB) is a childhood tumor that arises from the sympathoadrenal lineage. MYCNamplification is the most reliable marker for poor prognosis and MYCN overexpression in embryonic mouse sympathetic ganglia results in NB-like tumors. MYCN cooperates with mutational activation of anaplastic lymphoma kinase (ALK), which promotes progression to NB, but the role of MYCN and ALK in tumorigenesis is still poorly understood. Here, we use chick sympathetic neuroblasts to examine the normal function of $M Y C N$ and $M Y C$ in the control of neuroblast proliferation, as well as effects of overexpression of $M Y C N, M Y C$, and activated ALK, alone and in combination. We demonstrate that MYC is more strongly expressed than MYCN during neurogenesis and is important for in vitro neuroblast proliferation. MYC and MYCN overexpression elicits increased proliferation but does not sustain neuroblast survival. Unexpectedly, long-term expression of activated $A L K^{F 1174 L}$ leads to cell-cycle arrest and promotes differentiation and survival of postmitotic neurons. $A L K^{F 1174 L}$ induces $N E F M, R E T$, and VACHT and results in decreased expression of proapototic (BMF, BIM), adrenergic (TH), and cell-cycle genes (e.g., $C D C 25 A, C D K 1$ ). In contrast, neuroblast proliferation is maintained when $M Y C N$ and $A L K^{F 1174 L}$ are coexpressed. Proliferating MYCN/ALK ${ }^{F 1174 L}$ neuroblasts display a differentiated phenotype but differ from $A L K$-expressing neurons by the upregulation of SKP2, CCNA2, E2F8, and DKC1. Inhibition of the ubiquitin ligase SKP2 (S-phase kinase-associated protein 2), which targets the CDK inhibitor p27 for degradation, reduces neuroblast proliferation, implicating SKP2 in the maintained proliferation of $M Y C N /$ $A L K^{F 1174 L}$ neuroblasts. Together, our results characterize MYCN/ALK cooperation leading to neuroblast proliferation and survival that may represent initial steps toward NB development.

Key words: ALK; MYCN; neuroblast; neuroblastoma; neurogenesis; sympathetic

Significance Statement

MYCN overexpression combined with activated anaplasticlymphoma kinase (ALK) is sufficient to induce neuroblastoma (NB) in mouse sympathoadrenal cells. To address cellular and molecular effects elicited by MYCN/ALK cooperation, we used cultures of chick sympathetic neuroblasts. We demonstrate that $M Y C N$ increases proliferation but not survival, whereas long-term expression of $A L K^{F 1174 L}$ elicits cell-cycle exit, differentiation, and survival of postmitotic neurons. Combined MYCN/ALK ${ }^{F 1744 L}$ expression allows long-term proliferation and survival of neuroblasts with differentiated characteristics. In the presence of $A L K^{F 1174 L}$ signaling, $M Y C N$ induces the expression of the ubiquitin ligase SKP2 (S-phase kinase-associated protein 2), which targets p27 for degradation and is also upregulated in high-risk NB. SKP2 inhibition supports a function for SKP2 in the maintained neuroblast proliferation downstream of MYCN/ALK, which may represent an early step toward tumorigenesis.

\section{Introduction}

Neuroblastoma (NB) is a childhood tumor that develops from neural crest-derived cells in sympathetic ganglia and adrenal me-

\footnotetext{
Received Jan. 18, 2016; revised July 25, 2016; accepted Aug. 23, 2016.

Author contributions: H.R. designed research; M.K., D.R., and H.R. performed research; M.A.H. contributed unpublished reagents/analytic tools; M.K., D.R., and H.R. analyzed data; M.K., D.R., M.A.H., T.D., and H.R. wrote the paper.

This work was supported by grants from the Wilhelm-Sander-Stiftung to H.Rand grants from the Swedish Cancer Society and Swedish Research Council to M.A.H. We thank Nikolay Zinin for technical support, Pascal Fries for support, Dorothea Schulte for discussion, and Uwe Ernsberger and Isabelle Janoueix-Lerosey for helpful comments on the manuscript.
}

dulla. NB displays a broad clinical spectrum that correlates with differentiation state. High-risk disease involving undifferentiated, metastatic tumors relapses in the majority of cases and is almost always fatal (Maris, 2010; Simon et al., 2011). A characteristic feature of high-risk NB is amplification of $M Y C N$, a

\footnotetext{
The authors declare no competing financial interests.

Correspondence should be addressed to Hermann Rohrer, Institute of Clinical Neuroanatomy, Goethe University Frankfurt/Main, Theodor-Stern-Kai 7, 60590 Frankfurt/Main, Germany. E-mail: hermann.rohrer@brain.mpg.de; rohrer@med.uni-frankfurt.de.

DOl:10.1523/JNEUROSCI.0183-16.2016

Copyright $\odot 2016$ the authors $\quad 0270-6474 / 16 / 3610425-15 \$ 15.00 / 0$
} 
proto-oncogene encoding MYCN that belongs, together with c-MYC (hereafter called MYC) and MYCL, to the MYC-family of helix-loop-helix-Zip transcription factors (Brodeur et al., 1984). Targeted expression of MYCN in tyrosine hydroxylase (TH)expressing cells of embryonic transgenic mice results in the postnatal generation of NB (Weiss et al., 1997; Hansford et al., 2004; Althoff et al., 2015).

Activating point mutations in the gene-encoding anaplastic lymphoma receptor tyrosine kinase (ALK) were discovered in the majority of familial and $\sim 8 \%$ of sporadic NB (Chen et al., 2008; George et al., 2008; Janoueix-Lerosey et al., 2008; Mosse et al., 2008). One of the most common somatic mutations results in a phenylalanine-to-leucine substitution at codon 1174 (F1174L). $A L K^{F 1174 L}$ is present in all NB subtypes, but in association with $M Y C N$ amplification it defines a subset of NB patients with poor outcome (De Brouwer et al., 2010). Expression of activated ALK in sympathoadrenal cells of transgenic and knock-in mice induced NB only when expressed transgenically using the strong $\beta$-actin promotor (Heukamp et al., 2012) but not when under control of the Th or endogenous Alk promotor (Berry et al., 2012; Cazes et al., 2014). Similarly, $A L K^{F 1174 L}$ expression was unable to induce NB in zebrafish (Zhu et al., 2012). In contrast, the combination of activated ALK and MYCN overexpression results in fully penetrant and rapid generation of NB without any additional genomic alterations (Berry et al., 2012; Heukamp et al., 2012; Cazes et al., 2014). Therefore, NB elicited by ALK/MYCN cooperation represents an interesting model to study cellular and molecular mechanisms of NB development. Comparing geneexpression profiles of ALK/MYCN with MYCN tumors identified (1) increased expression of components of the PI3K/AKT/ mTor and MAPK pathway, which results in stabilization of MYCN protein; (2) increased MYCN transcription; and (3) reduced apoptosis (Berry et al., 2012; Heukamp et al., 2012). In addition, the tyrosine kinase receptor RET is induced in ALK/ MYCN tumors and controls tumor growth (Cazes et al., 2014). Although the earlier onset and increased penetrance of tumor formation implies a function of these signaling conduits in tumor development, it remains unclear at which stage these mechanisms are effective. Neuroblasts may either be induced to expand from embryonic stages onwards or may depend for their postnatal survival on ALK/MYCN cooperation.

In embryonic sympathetic ganglia of both TH-MYCN and wild-type mice clusters of highly proliferating cells are present but selectively maintained postnatally in TH-MYCN ganglia (Hansford et al., 2004; Alam et al., 2009). In the Ki-Alk mouse, neuroblast proliferation is transiently increased in embryonic and early postnatal ganglia but terminated at postnatal day 18 (Cazes et al., 2014). The situation in sympathetic ganglia and adrenals coexpressing activated ALK and MYCN has not been investigated.

Here, we used chick sympathetic neuroblasts to investigate the effects and interactions of MYCN, MYC, and activated ALK on neuroblast proliferation and survival. We demonstrate that neuroblast proliferation depends mainly on MYC. Overexpression of MYCN or MYC supports continued high-level proliferation but not neuroblast survival. In contrast, $\mathrm{ALK}^{\mathrm{F} 1174 \mathrm{~L}}$-expressing neuroblasts display only an initial proliferation increase and subsequently leave the cell cycle, acquire a mature neuron morphology, and display increased survival. Importantly, the combined expression of $\mathrm{ALK}^{\mathrm{F} 1174 \mathrm{~L}}$ and MYC proteins supports both neuroblast proliferation and survival. Compared with $A L K^{F 1174 L}$ expressing neuroblasts, MYCN/ALK ${ }^{F 1174 L}$ cells maintain elevated levels of neuronal differentiation markers and show increased expression of the cell-cycle-related MYCN target genes SKP2, DKC1, E2F8, and CCNA2. Cell-cycle exit observed upon SKP2 (S-phase kinase-associated protein 2) inhibition supports a function of SKP2 in the control of MYCN/ALK $K^{F 1174 L}$ neuroblast proliferation.

\section{Materials and Methods}

Plasmid construction. Expression vectors used were constructed by cloning restriction enzyme-digested or PCR-amplified DNA fragments with standard protocols. The PiggyBac (PB-CAG-eGFP) and PBase $(m P B)$ expression vectors described previously (Cadiñanos and Bradley, 2007; Nagy et al., 2011), were obtained from the Wellcome Sanger Institute and from Andres Nagy at the Samuel Lunenfeld Research Institute, Mount Sinai Hospital, Toronto, Canada, respectively. $P B-C A G-e G F P$ was used as parental plasmid replacing $e G F P$ by either $M Y C, M Y C N$, or $A L K^{F 1174 L}$ or generating a control plasmid without $e G F P$ [PiggyBac (PB) control]. Plasmids containing human $M Y C N$ and $A L K^{F 1174 L}$ were generously provided by Christian Beltinger (University Clinic Ulm, Ulm, Germany) and by Isabelle Janoueix-Lerosey (Institut Curie, Paris, France), respectively. The chicken MYC plasmid has been described previously (Zinin et al., 2014).

Cell culture, electroporation, pharmacological treatment, and immunostaining. Paravertebral lumbosacral sympathetic chain ganglia were dissected from embryonic day (E) 7 chick embryos of either sex and dissociated to single cells as described previously (Rohrer and Thoenen, 1987; Zackenfels et al., 1995). Cells were either plated directly or transfected by electroporation using Amaxa Nucleofector II and the Basic Neuron Small Cell number (SCN) Nucleofector Kit (Program SCN2). For integration of MYC, MYCN, and $A L K^{F 1174 L}$ into the chick genome, the PB DNA-transposition method was applied (Ding et al., 2005), in which the genes of interest, cloned between the two PB arms of the PB vector pCYL50 are cotransfected with Pbaseexpression vector (for a schematic representation of the PB system, see Woodard and Wilson, 2015). Specifically, cells were cotransfected with GFPexpression vector and $\mathrm{PB}$ (controls) or with GFP-expression vector, $\mathrm{PB}$, and PB-expression vectors for $M Y C, M Y C N$, and $A L K^{F 1174 L}$. For knockdown experiments, cells were also electroporated with siRNA against MYC, $M Y C N$, or with control siN1. The following concentrations of DNA or RNA were used: $P B$-CAG-eGFP $(0.25 \mu \mathrm{g} / 200,000$ cells $), P B-C A G-N M Y C(0.25$ $\mu \mathrm{g} / 200,000$ cells), $P B-C A G-C m y c(0.25 \mu \mathrm{g} / 200,000$ cells $), P B-C A G-$ $A L K^{F 1174 L}(0.2 \mu \mathrm{g} / 200,000$ cells), mPBase ( $0.3 \mu \mathrm{g} / 200,000$ cells), and empty $P B$-CAG vector $(0.25 \mu \mathrm{g} / 200,000$ cells) as control. iBONI siRNA Quattro siGgMYCN (50 pmol of each siRNA/200,000 cells; Riboxx), iBONI siRNA siGgMYCN(1) 5'-UAUUUCUUCUUCAUCAUCCCCC-3' (Riboxx), siRNA siGgMYCN(2) 5'-CAACAGUUGCUAAAGAAAACCCCC-3' (Riboxx), siRNA siGgMYCN(3) 5'-CGCCAAUUCACCAGCAGCAUAAU UA-3' (Invitrogen Block-iT; stealth 905), siRNA siGgMYC 5'-AGAUCAGCAACAACCGAAA-3' (Eurofins Genomics; all at 100 pmol siRNA/200,000 cells; Eurofins Genomics) and, as control, iBONI siRNA Negative Control-N1 and Invitrogen Block-iT control 3'-UAAUGUUGUA GUCGUCGUGUAAGCG-5' (200 pmol/200,000 cells). After nucleoporation, cell debris was removed by density step-gradient centrifugation and 15,000 cells were plated per well on four-well culture dishes coated with 0.5 $\mathrm{mg} / \mathrm{ml}$ poly-DL-ornithine (Sigma-Aldrich) in $0.15 \mathrm{~m}$ borate buffer, $\mathrm{pH} 8.3$, and $10 \mu \mathrm{g} / \mathrm{ml}$ laminin (Invitrogen) in PBS, $\mathrm{pH} 7.3$, and cultured in MEM, $10 \%(\mathrm{v} / \mathrm{v})$ horse serum, $5 \%(\mathrm{v} / \mathrm{v})$ fetal calf serum, $1 \%(\mathrm{w} / \mathrm{v})$ penicillin/ streptomycin, and $1 \%(\mathrm{w} / \mathrm{v})$ glutamine at $5 \% \mathrm{CO}_{2}$. Where indicated, $2 \%$ chick embryo extract (CEE) was added to the medium to support long-term survival (Haltmeier and Rohrer, 1990). BET bromodomain protein inhibitor JQ1 (ab141498, Abcam), RET inhibitor vandetanib (15706, Cayman Chemical), and SKP2 inhibitor SKPin C1 (4817, Tocris Bioscience) were dissolved in sterile DMSO at $10 \mathrm{~mm}$ (JQ1, C1) or $5 \mathrm{~mm}$ (vandetanib) and diluted to appropriate final concentrations in medium. Proliferating neuroblasts were detected by 5-ethynyl-2-deoxyuridine (EdU) labeling using the Click-iT EdU Alexa Fluor 647 imaging kit (Invitrogen) as described previously (Reiff et al., 2011; Holzmann et al., 2015) combined with immunostaining for TH and GFP or Alk and GFP. GFP expression was analyzed by staining with anti-GFP antibody (1:400, rabbit, polyclonal; A-11122, Invitrogen) followed by Alexa 488 anti-rabbit as secondary antibody. TH expres- 


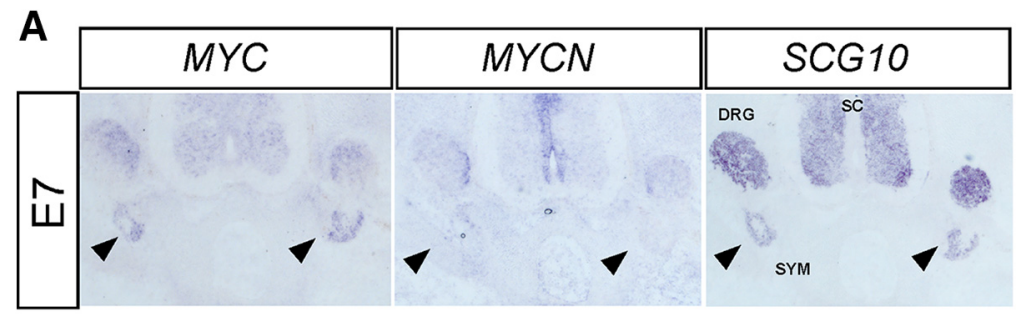

B

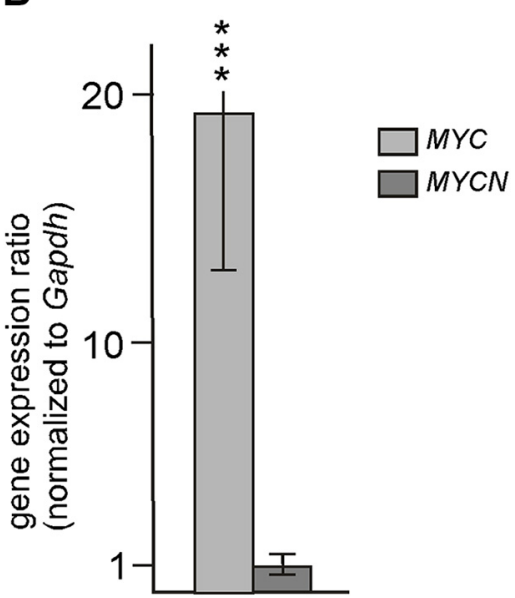

Figure 1. Expression of $M Y C N$ and $M Y C$ in developing chick sympathetic ganglia. $A$, ISH for $M Y C$ and $M Y C N$ on sections of $E 7$ chick sympathetic ganglia reveals much lower signals for MYCN compared with the strong MYC expression. SCG10 expression is shown to illustrate the location of sympathetic ganglia (SYM), dorsal root ganglia (DRG), and spinal cord (SC). Arrowheads point to sympathetic ganglia. B. High MYC expression compared with MYCN is shown by qRT-PCR on dissected E7 sympathetic ganglia (mean \pm $\mathrm{SE}^{* * *} p<0.001$; statistical analysis by relative expression software tool).

sion was detected by staining with anti-TH antibody (1:50, mouse, monoclonal; generated and characterized previously; Rohrer et al., 1986; Bonnefoy et al., 1988) followed by Alexa 546 anti-mouse secondary antibody. Alk expression was detected by anti-ALK antibody (1:1000, rabbit, monoclonal; \#3633, Cell Signaling Technology) followed by Alexa 546 anti-rabbit secondary antibody. Cell nuclei were visualized with DAPI (Sanofi Aventis). Images were acquired at a magnification of $20 \times$ using Zeiss AxioImager.Z1 equipped with an AxioCam MRm camera.

The proportion of EdU-labeled, TH-positive, or Alk-positive and GFP-positive transfected neuroblasts was quantified in $\geq 3$ independent experiments. For cell survival, the number of TH-positive and GFPpositive cells was determined for each experiment on 20 arbitrarily chosen visual fields per cultured dish and $\geq 3$ independent experiments were evaluated. For apoptosis assays, the percentage of transfected GFPpositive cells with pyknotic nuclei was determined in five independent experiments. All results are provided as mean \pm SEM of $\geq 3$ independent experiments and statistically analyzed with unpaired two-tailed Student's $t$ test or one-way ANOVA with the Tukey-Kramer multiple comparisons test.

In situ hybridization. In situ hybridization (ISH) for MYC, MYCN, and SCG10 was performed in fixed tissue as described previously (Zinin et al., 2014; Ribeiro et al., 2016). Briefly, E7-derived sections were incubated with digoxigenin-labeled single-stranded RNA probes at $72^{\circ} \mathrm{C}$ for $M Y C$ and $M Y C N$ and $68^{\circ} \mathrm{C}$ for SCG10, followed by incubation with alkaline phosphatase-coupled antibody and nitroblue tetrazolium plus 5-bromo4-chloro-3-indolyl phosphate (purple) substrates.

Chicken embryo electroporation. In ovo electroporation was performed as previously described (Kaltezioti et al., 2010). Briefly, white Leghorn chicken eggs were incubated until Hamburger Hamilton stage 12-14 (E2). Plasmids were used at a concentration of $1-2 \mathrm{mg} / \mathrm{ml}$ with $0.025 \%$ Fast Green (Sigma-Aldrich), injected into the lumen of the neural tube (10 $\mu$ l total volume). For PB transposition, a 2:1 ratio of transposon
(PB-CAG-GFP alone or with PB-CAG$\mathrm{MYCN}$ ) and transposase (PBase) was used. Electrodes were spaced $4 \mathrm{~mm}$ part and positioned lateral to the neural tube. Embryos were pulsed $3 \times$ for $30 \mathrm{~ms}$ each at $28 \mathrm{~V}$. Eggs were reincubated for $3 \mathrm{~d}$ followed by fixation for $4 \mathrm{~h}$ at $4^{\circ} \mathrm{C}$ in $4 \%$ paraformaldehyde in PBS. Embryos were washed in PBS, cryoprotected with $20 \%$ sucrose, mounted in Tissue Tec (Sakura Fintek), and sectioned at $12-14 \mu \mathrm{m}$. For EdU labeling, embryos received $500 \mu \mathrm{M}(500 \mu \mathrm{l})$ EdU in PBS $4 \mathrm{~h}$ before fixation. Sections were triple-stained for GFP, TH, and EdU and analyzed for the percentage of EdUlabeled, transfected Th-expressing neuroblasts on $\geq 20$ sections per embryo. Electroporation experiments were quantified from seven control and seven MYCNtransfected embryos.

qRT-PCR analysis. For qRT-PCR analysis of cultured sympathetic ganglion cells, cultures were kept on poly-DL-ornithine/laminin-coated $3.5 \mathrm{~cm}$ culture dishes. After 2 or $8 \mathrm{~d}$ of cultivation, cells were harvested with a cell scraper and RNA was isolated using the RNeasy Kit (Qiagen) following the manufacturer's instructions. qRTPCR was performed using the QuantiTect SYBR Green PCR Kit with the following QuantiTect primer assays (Qiagen): Gg_MAD2L1_1_SG; Gg_CCNA2_1_SG; Gg_PLK1_2_SG; Gg_SOX 11_1_SG; Gg_SMC2_1_SG; Gg_CDK1_1_SG; Gg_SKP2-2-SG; Gg_E2F8_1_SG; Gg_CDC25A_ 1_SG; Gg-DKC1_1_SG; Gg_GAPDH_1_SG; Gg_SLC18A3_1_SG; Gg_BCL2L1_1_SG; Gg $B M F \_1 \_S G ;$ Gg_BOK_1_SG; Gg_VIP_1_SG; Gg_MYC_1_SG; Gg_NEFM_1_SG; Gg_DBH_ 1_SG; Gg_TH_1_SG; Gg_RET_1_SG; Gg BIRC5_1_SG; Gg_BID_1_SG; Gg_BCL2_1_SG; Gg_MYCN_1_SG; Gg_TLX3_1_SG; Gg_LIN28B_1_SG; Gg_NTRK1_1_SG. Note that GgMYCN primers do not recognize human $M Y C N$ used for overexpression experiments. The temperature profile for all qPCR experiments was the following: $95^{\circ} \mathrm{C}$ for $15 \mathrm{~min}$ and 40 cycles $\left(94^{\circ} \mathrm{C}\right.$ for $15 \mathrm{~s}, 55^{\circ} \mathrm{C}$ for $30 \mathrm{~s}, 72^{\circ} \mathrm{C}$ for $30 \mathrm{~s})$. At least triplets of every condition were performed in parallel and experiments were repeated independently at $\geq 3$ times. Data are normalized to GAPDH as reference genes, expressed as a gene expression ratio, and statistically evaluated using the relative expression software tool (Pfaffl et al., 2002).

\section{Results}

MYCN and MYC are coexpressed in sympathetic neuroblasts during neurogenesis

In the embryonic chick spinal cord and dorsal root ganglia, $M Y C$ and $M Y C N$ mRNA are expressed in a mirror image pattern (Zinin et al., 2014). MYCN is restricted to SOX2-positive proliferating progenitors, whereas $M Y C$ is observed in differentiated Islet1-expressing neurons. In sympathetic ganglia, MYC is expressed at much higher levels compared with $M Y C N$ as judged from ISH and qRT-PCR analysis of sympathetic ganglia dissected at E7 (Fig. 1). Similar results were obtained for cultures of E7 sympathetic ganglion cells ( 15 -fold higher by qRT-PCR; $n=3$; $p<0.05)$. E7 represents the peak of neurogenesis in chick sympathetic ganglia, which are mainly composed of proliferating neuroblasts at this developmental stage (Holzmann et al., 2015). In view of the strong difference in their expression levels (Fig. 1), it was of interest to investigate to which extent neuroblast proliferation depends on $M Y C$ and/or MYCN. 

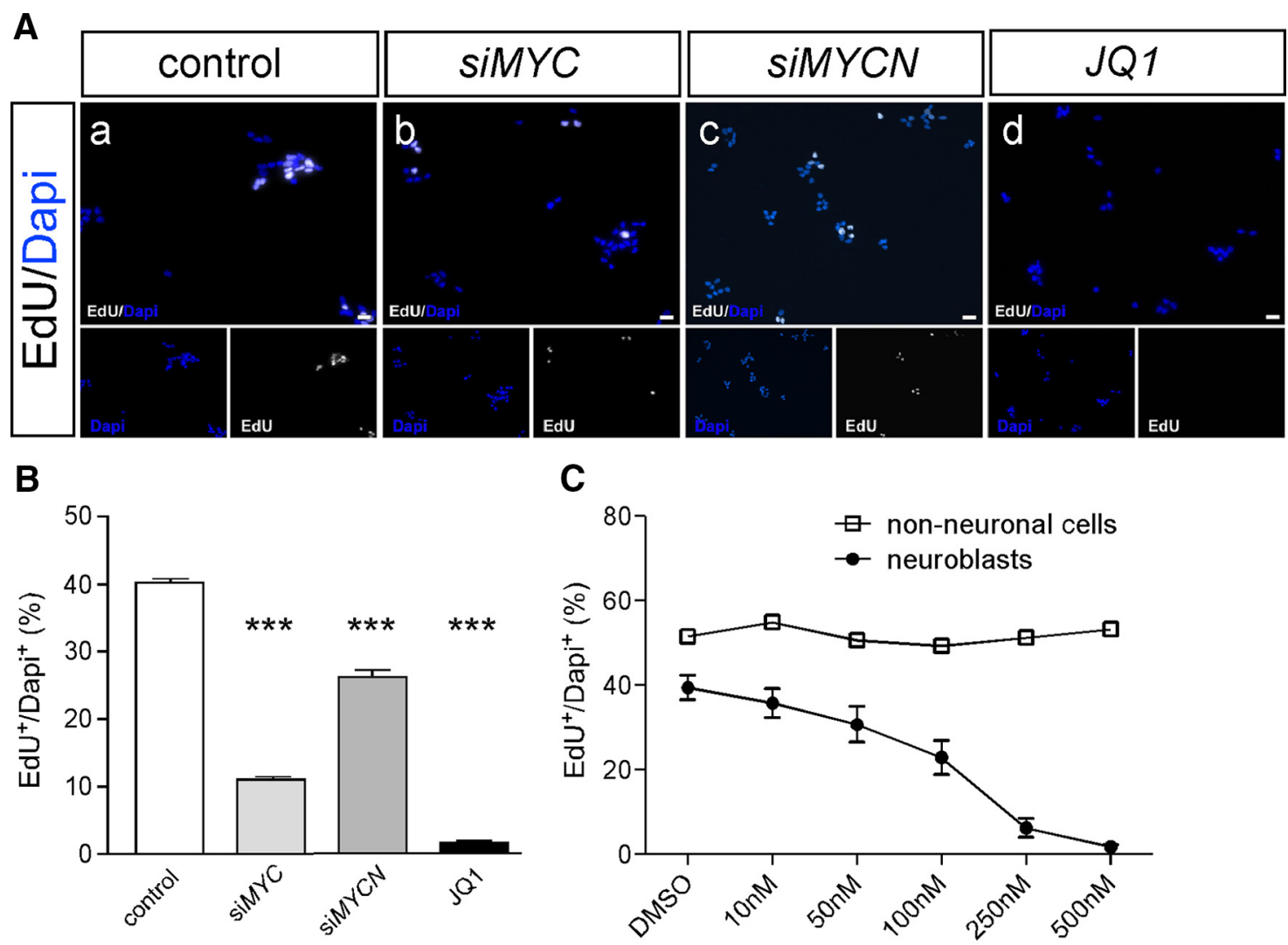

C

D

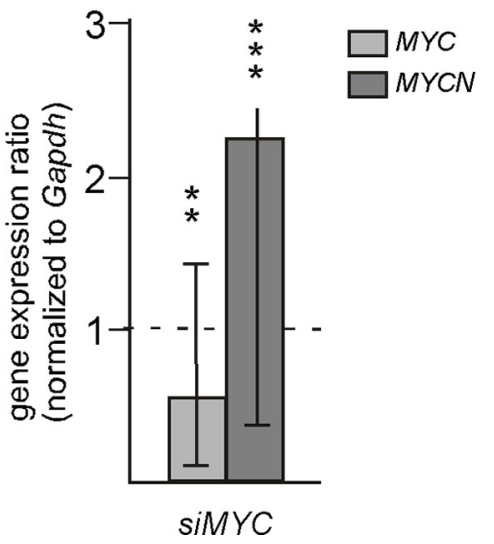

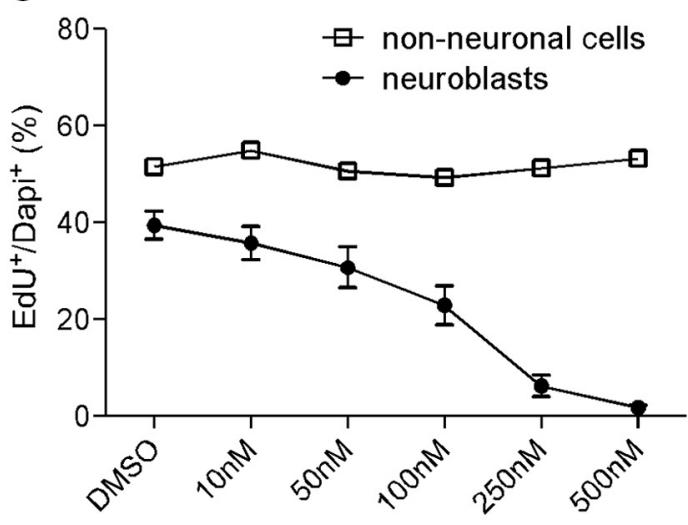

$\mathbf{E}$

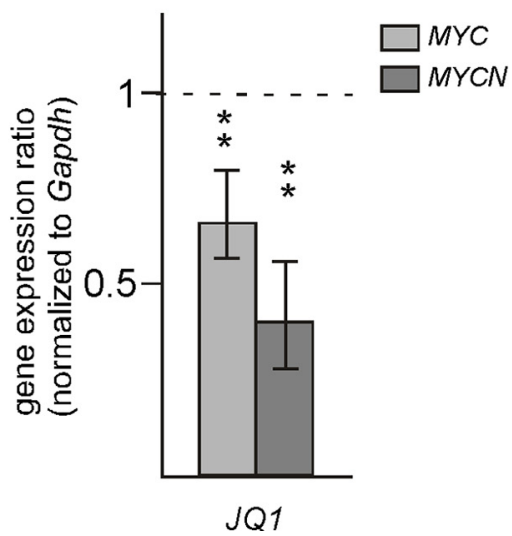

Figure 2. Proliferation of $\mathrm{E} 7$ sympathetic neuroblasts depends on MYC signaling. $\boldsymbol{A}$, The number of proliferating neuroblasts, identified by EdU labeling ( $\boldsymbol{A} \boldsymbol{a}-\boldsymbol{A d})$ is reduced by siMYC ( $\boldsymbol{A} \boldsymbol{b})$, $\operatorname{siMYCN(2)}(\boldsymbol{A c})$, and JQ1 (Ad). Scale bar, $20 \mu \mathrm{m}$. B, Quantification of neuroblast proliferation in cells transfected with control siN1, siMYC, siMYCN(2), or treated with JQ1 (500 nM; mean \pm SEM; $n \geq 3$; $\left.{ }^{* *} p<0.001\right)$. C, Dose-response of the antiproliferation effect of JQ1. Whereas neuroblast proliferation is blocked at $500 \mathrm{~nm}$, non-neuronal cell proliferation is not affected by JQ1. Non-neuronal cells were identified by the much larger size of their nucleus compared with neuroblasts. D, E, siMYC treatment leads to a significant reduction in MYC RNA and upregulation of MYCN RNA (D), whereas JQ1 treatment reduces both MYC and MYCN expression as shown by qRT-PCR $\left(\boldsymbol{E}\right.$; mean $\pm \mathrm{SE} ;{ }^{* *} p<0.01$; ${ }^{* * *} p<0.001$; statistical analysis by relative expression software tool).

\section{Proliferation of sympathetic neuroblasts depends on MYC proteins}

Neuroblast proliferation was analyzed in cultures of dissociated E7 chick sympathetic ganglia by EdU labeling as described previously (Zackenfels et al., 1995; Reiff et al., 2010, 2011). E7 is the earliest age sympathetic ganglia can be reliably dissected from the chick embryo. To investigate the role of MYC proteins in neuroblast proliferation, siRNA directed against MYC or MYCN was used (Zinin et al., 2014). siMYC led to a reduction in the proportion of proliferating EdU-labeled cells to $30 \pm 0.5 \%$ of control siRNA cultures, whereas MYCN knockdown by siMYCN(2) had a much smaller effect (reduction to $67 \pm 5 \%$; Fig. $2 A, B$ ). Prolifer- ation was reduced to a similar level in response to two additional siMYCN RNAs [siMYCN(1), siMYCN(3)] and an siMYCN RNA mixture (see Materials and Methods; data not shown).

$M Y C$ mRNA level is decreased and MYCN mRNA is upregulated by siMYC as shown by qRT-PCR (Fig. 2D), which is consistent with previous evidence for inverse correlation between $M Y C$ and MYCN expression (Breit and Schwab, 1989; Henriksen et al., 2011; Zinin et al., 2014). Increased MYCN expression is unlikely to functionally compensate for the loss of MYC since $M Y C N$ is expressed at much lower levels than $M Y C$ in vivo (Fig. 1) and in cultured cells (see above). MYCN RNA levels were not affected by treatment with several different $M Y C N$ siRNAs. This may be ex- 
plained by previous observations in NB cell lines that $M Y C N$ RNA, in contrast to $M Y C N$ protein, is affected only transiently by siRNA treatment (Bell et al., 2007; Henriksen et al., 2011). Together, expression and knockdown results suggest that MYC rather than $M Y C N$ is important for neuroblast proliferation during sympathetic neurogenesis.

As the BET bromodomain protein inhibitor JQ1 interferes with the expression of MYC and MYCN in tumor-cell lines and inhibits MYC-dependent tumor growth (Delmore et al., 2011; Heukamp et al., 2012; Puissant et al., 2013; Henssen et al., 2016), we also investigated the effects of JQ1 treatment in primary sympathetic neuroblast cultures. Proliferation was efficiently blocked by JQ1, with half-maximal effects at $100 \mathrm{nM}$ and complete inhibition at $500 \mathrm{~nm}$ (Fig. 2B,C). MYC and MYCN levels were both reduced (Fig. 2E). The virtually complete block in neuroblast proliferation cannot be explained by the rather mild reduction in MYC and MYCN levels, which implies an action of JQ1 on MYC targets in addition to controlling MYC expression (Henssen et al., 2016). Notably, JQ1 did not interfere with the proliferation of ganglion non-neuronal cells present in the culture, excluding a nonspecific proliferation block (Fig. 2C).

\section{Overexpression of $M Y C N$ and $M Y C$ leads to maintained} neuroblast proliferation in vitro but does not sustain survival In normal cells, expression of MYC family members is low and depends continuously on mitogenic signaling. Elevated levels are observed in many cancers, including NB where deregulated $M Y C N$ expression correlates with bad prognosis. To study effects of MYC protein overexpression, chick sympathetic neuroblasts were transfected with plasmids designed for genomic integration by Piggybac $(\mathrm{Pb})$ transposase, allowing permanent expression (Ding et al., 2005; Lu et al., 2009; Nagy et al., 2011; Woodard and Wilson, 2015). As normal neuroblast proliferation depends on MYC, rather than MYCN, the effects of both MYC proteins were analyzed. Neuroblasts were cotransfected with Pb-flanked CAGGS-GFP, CAGGS-MYC, or CAGGS-MYCN and an episomally expressed $\mathrm{Pb}$ transposase plasmid. Transfected neuroblasts, identified by coexpression of GFP and TH, were analyzed for proliferation by EdU labeling after 2 and $8 \mathrm{~d}$ in culture (dic; Fig. 3). The proportion of EdU ${ }^{+} / \mathrm{TH}^{+}$-labeled transfected cells is significantly increased by both $M Y C N$ and $M Y C$ expression at 2 and $8 \mathrm{dic}$ (Fig. $3 \mathrm{~B}, \mathrm{C}$ ). MYCN overexpression increases cell numbers at 8 dic compared with GFP-transfected controls (Fig. 3E), but increased proliferation in response to MYC or MYCN does not result in a net increase in cell numbers compared with 2 dic (Fig. 3, compare $D, E$ ), which suggests that overexpression of MYC proteins is unable to maintain neuroblast survival. With increasing time in culture, survival of MYC-expressing and MYCN-expressing cells is further decreased, which may in part be due to tumor suppressor and apoptosis pathways induced by oncogenic levels of MYC proteins (Lowe et al., 2004). This notion is supported by the finding that the percentage of apoptotic cells is increased by MYCN expression (Fig. 3E).

\section{MYCN overexpression increases neuroblast proliferation in vivo}

MYCN is sufficient to elicit NB development, but in $M Y C N$ mouse NB models, neuroblast proliferation and sympathetic ganglion size are not increased during embryonic and early postnatal development (Hansford et al., 2004; Alam et al., 2009; Althoff et al., 2015). To address the in vivo effects of MYCN overexpression in chick sympathetic neuroblasts, we electroporated neural crest cells in 2-d-old (E2) chick embryos with Pb- flanked CAGGS-GFP, CAGGS-MYCN, and $\mathrm{Pb}$ plasmid and analyzed $\mathrm{E} 5$ embryos for the proportion of proliferating $\mathrm{EdU}^{+} /$ $\mathrm{TH}^{+} / \mathrm{GFP}^{+}$neuroblasts. MYCN overexpression leads to a significantly increased proliferation of sympathetic neuroblasts compared with control GFP-transfected embryos (Fig. 4). Thus, $M Y C N$ is sufficient to increase chick neuroblast proliferation both in vitro and in vivo. Only a small proportion of sympathetic ganglion cells was transfected and thus effects on ganglion size and survival could not be investigated.

\section{Expression of constitutively active $A L K^{F 1174 L}$ interferes with neuroblast proliferation and induces neuron differentiation and survival}

As baseline for investigating the interaction between MYC proteins and activated ALK in cultured sympathetic neuroblasts, the long-term effects of activated ALK signaling were analyzed using the Piggybac transposon system. Constitutively active ALK increases neuroblast proliferation in short-term $(2 \mathrm{dic})$ cultures (Fig. 5A, B; Reiff et al., 2011). Unexpectedly, proliferation is completely arrested after $8 \mathrm{dic}$ (Fig. $5 A, B$ ). This seems not to be due to death of proliferating cells but rather to increased differentiation, reflected by mature morphology, including large, phase-bright cell bodies and a high number of long, branched neurites (Fig. $5 A d$ ). Indeed, the number of $A L K^{F 1174 L}$-transfected cells surviving up to 8 dic is significantly higher than the number of control transfected cells (Fig. 5C). ALK ${ }^{F 174 L}$-induced differentiation generates sympathetic neurons that can be maintained for several weeks in culture (Fig. 5D). Increased neuronal differentiation of $A L K^{F 1174 L}$-expressing sympathetic neuroblasts compared with $M Y C N$-transfected cells is also reflected by augmented expression of differentiation genes, analyzed by qRT-PCR at 8 dic (Fig. 6). $A L K^{F 1174 L}$-transfected cells were compared with $M Y C N$ transfected rather than GFP-transfected control cells because it was not possible to get sufficient RNA due to the poor survival of the latter (Fig. 5Ac). As expected from the differentiated neuronal morphology of $A L K^{F 1174 L}$ cells, the pan-neuronal gene NEFM is strongly upregulated. The increase in RET and SLC18A3 $(V A C H T)$, together with decreased TH expression suggests a shift toward cholinergic differentiation observed also in ALKinduced NB (Cazes et al., 2014; Lambertz et al., 2015; Fig. 6). It should be noted, however, that $\mathrm{TH}$ expression is maintained in ALK-induced sympathetic neurons (Fig. 5D). Decreased MYCN, MYC, TLX3, LIN28B, and BIRC5 expression correlate with decreased proliferation and/or loss of properties characteristic for early neuroblasts in $A L K^{F 1174 L}$-transfected versus $M Y C N$ transfected cultures (Huang et al., 2013; Hennchen et al., 2015). The long-term survival of $A L K^{F 1174 L}$-induced differentiated neurons may be explained by a decreased expression of the proapoptotic genes $B M F$ and BID. As expected for cultures mainly composed of postmitotic sympathetic neurons, the expression of genes involved in cell-cycle regulation and mitosis $(C D C 25 A$, E2F8, SKP2, MAD2L1, DKC1, PLK1, CCNA2, CDK1, SMC2) and of a gene-controlling sympathetic neuroblast proliferation (SOX11; Potzner et al., 2010) are reduced in $A L K^{F 1174 L}$ cultures compared with proliferating $M Y C N$-driven neuroblast cultures.

\section{$\mathrm{ALK}^{\mathrm{F1174L}}$ and MYC proteins cooperate to maintain long-} term sympathetic proliferation and survival

To analyze whether cooperative interactions between activated ALK and MYCN described in mouse and zebrafish NB models (Berry et al., 2012; Heukamp et al., 2012; Zhu et al., 2012; Cazes et al., 2014) also take place in embryonic chick sympathetic neuroblasts, $A L K^{F 1174 L}$ and MYC or MYCN piggybac plasmids were 
A
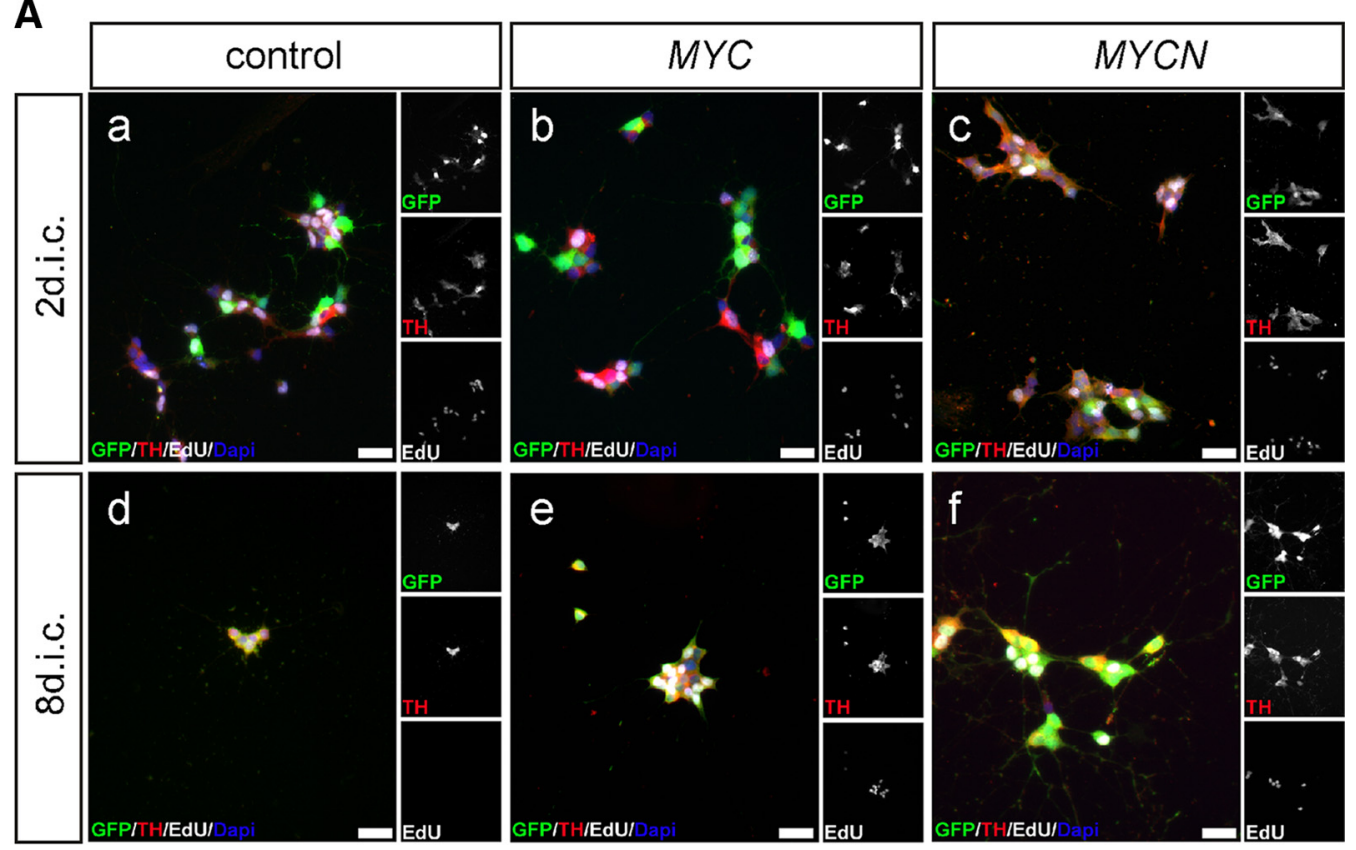

B

C
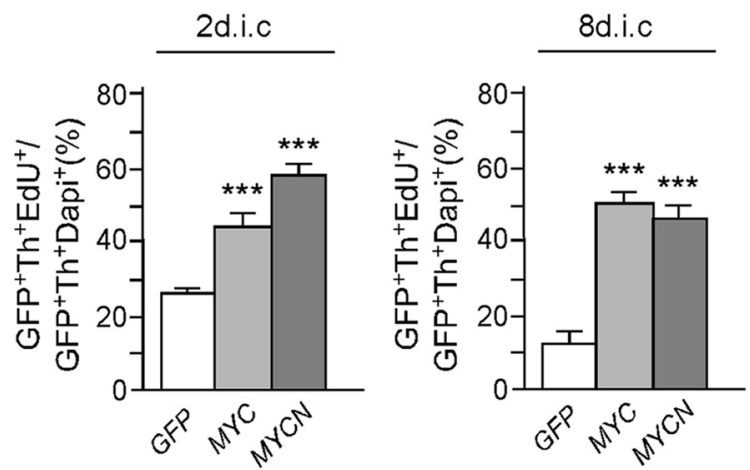

D

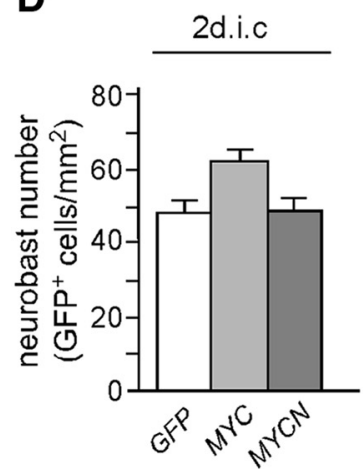

$\mathbf{E}$

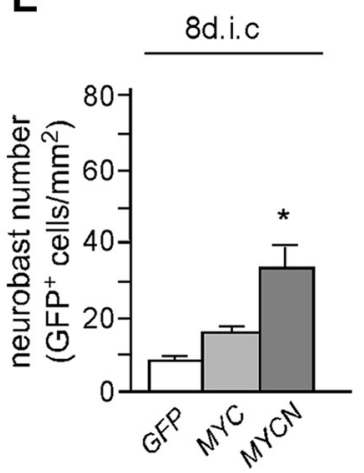

$\mathbf{F}$

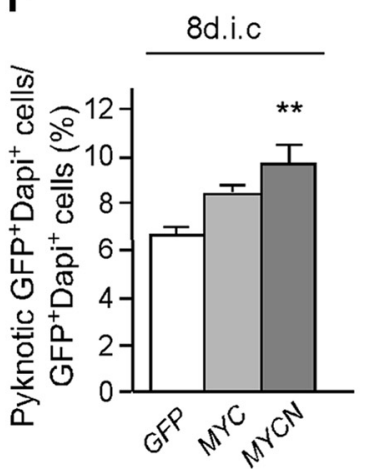

Figure 3. Sympathetic neuroblast proliferation is increased by MYC and MYCN overexpression. $A$, E7 sympathetic ganglion cells were transfected with expression vectors for GFP ( $A \boldsymbol{a}, \boldsymbol{A d})$, GFP and MYC ( $\boldsymbol{A} \boldsymbol{b}, \boldsymbol{A e})$, or GFP and MYCN $(\boldsymbol{A} \boldsymbol{c}, \boldsymbol{A} \boldsymbol{f})$ and analyzed by GFP/Th/EdU-triple immunostaining after $2(\boldsymbol{A} \boldsymbol{a}-\boldsymbol{A c})$ and $8 \mathrm{dic}(\boldsymbol{A d}-\boldsymbol{A f})$ for proliferating EdU-incorporating neuroblasts. Scale bar, $20 \mu \mathrm{m}$. $B, C$, Quantification reveals a significantly increased proliferation of MYC-expressing or MYCN-expressing neuroblasts compared with GFP controls at $2(\boldsymbol{B})$ and 8 dic $(\boldsymbol{C} ;$ mean $\pm S E M ; n \geq 3$; $* * * p<$ 0.001). D, Neuroblast number is not significantly increased compared with controls at 2 dic. $E$, Neuroblast number in control and MYC cultures are strongly decreased at 8 dic compared with 2 dic. Overexpression of MYCN increases the number of surviving neuroblasts at 8 dic (mean \pm SEM; $n \geq 3 ;{ }^{*} p<0.05$ ). $\boldsymbol{F}$, The percentage of pyknotic cells is increased in MYC-expressing or MYCN-expressing neuroblasts, not quite reaching significance for MYC (mean \pm SEM; $n=5 ;{ }^{* *} p<0.01$ ).

cotransfected (Fig. 7). Interestingly, proliferating neuroblasts are maintained in these cultures, which is demonstrated by the presence of EdU-labeled neuroblasts not observed in $A L K^{F 1174 L}$ cultures at 8 dic (Fig. $7 A d-A f, B)$. Triple-immunostaining for ALK/ GFP/EdU demonstrated that transfected ALK-expressing cells have incorporated the S-phase marker EdU (Fig. $7 D, E)$. Whereas in $A L K^{F 1174 L}$ cultures, EdU-labeled cells are virtually absent at 8 dic (Figs. $5 A d, 7 A d, D, E), 24 \pm 2.6 \%$ (mean \pm SEM; $n=5)$ of $\mathrm{ALK}^{+} / \mathrm{GFP}^{+}$cells are EdU-labeled in MYCN/ALK $K^{F 174 L}$ cultures (Fig. 7E). The higher percentage of GFP/Th/EdU cells compared 
A
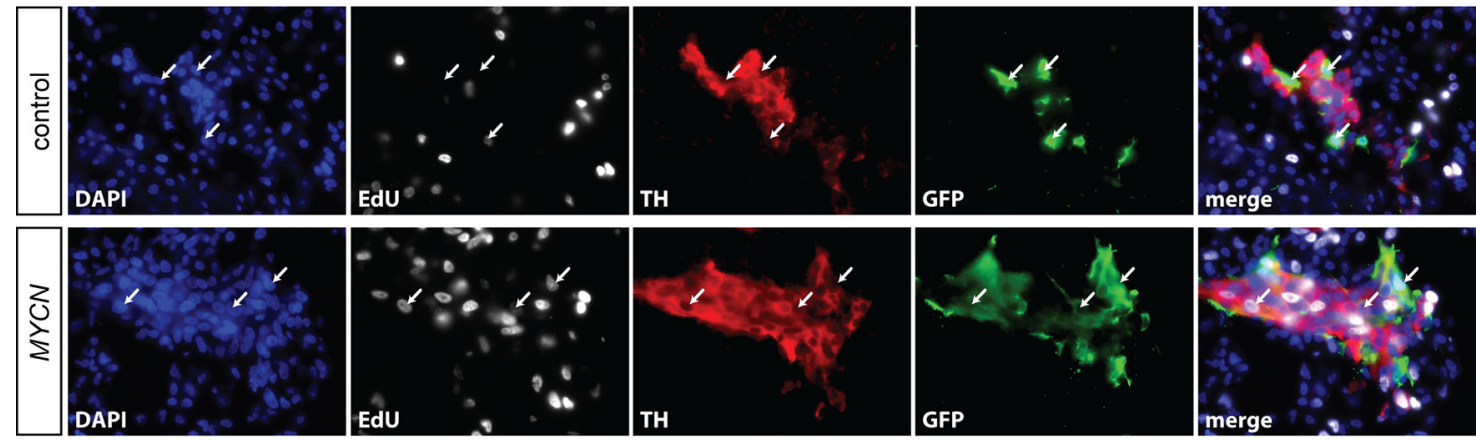

B

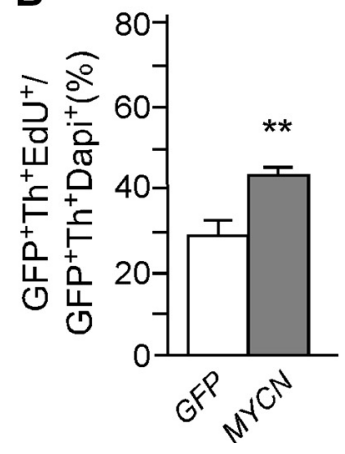

Figure 4. MYCN overexpression increases neuroblast proliferation in vivo. $\boldsymbol{A}$, Migrating neural crest cells were transfected by electroporation with $\mathrm{Pb}$ plasmid and piggybac transposon vectors for GFP (control) or GFP and MYCN (MYCN). At E5, proliferating cells were labeled by an EdU pulse and, after fixation of the embryo, cross sections from the GFP-expressing transfected area were triple-immunostained for EdU, Th, and GFP. B, Quantification of the percentage of EdU-labeled GFP ${ }^{+} / \mathrm{Th}^{+}$neuroblasts reveals a significant increase in $M Y C N$-expressing cells (mean \pm SEM; $n=7$; $\left.{ }^{* *} p<0.01\right)$. Arrows point to $\mathrm{GFP}^{+} / \mathrm{Th}^{+}$neuroblasts with increased EdU-labeling in MYCN transfected cells.

with GFP/ALK/EdU cells (Fig. $7 B, E$ ) may reflect the presence of a small subpopulation of proliferating cells with low or absent ALK expression. The vast majority of neuroblasts in $\mathrm{MYC} /$ $A L K^{F 1174 L}$ and MYCN/ALK $K^{F 1174 L}$ cells show a differentiated morphology, which is distinct from cells expressing either MYCN/ $M Y C$ or $A L K^{F 1174 L}$. They have increased cell-body size and neurite growth compared with MYCN/MYC cells, but remain smaller and display thinner neurites compared with $A L K^{F 1174 L}$ expressing neurons (compare Figs. 3Ae, $A f, 5 A d$, 7Ad-Af). Comparative gene expression analysis of a number of marker genes by qRT-PCR revealed only relatively minor differences between $M Y C N / A L K^{F 1174 L}$ and $A L K^{F 1174 L}$ cultures (Fig. 8A). The unchanged expression levels of TLX3,TRKA,TH, DBH, NEFM, $L I N 28 B$, and RET argues against major effects of $M Y C N$ on differentiated properties of $A L K^{F 1174 L}$-transfected cells. The downregulation of endogenous chicken $M Y C N$ is explained by negative autoregulation in response to overexpressed human MYCN (Penn et al., 1990; Luo et al., 2004), which is not detected by the chicken-specific qRT-PCR primers. Although all analyzed genes controlling cell cycles and mitosis were previously shown to be direct or indirect MYCN target genes (Westermann et al., 2008; Otto et al., 2009; Bell et al., 2010; Valentijn et al., 2012; Puissant et al., 2013), only a subset (i.e., SKP2, CCNA2, DKC1, and $E 2 F 8$ ) is induced when MYCN is acting in combination with ALK signaling. Notably, SKP2, CCNA2, DKC1, and E2F8 expression is also significantly increased in $M Y C N / A L K^{F 1178 L}$ mouse NB compared with $A L K^{F 1178 L}$ sympathetic ganglia (Cazes et al., 2014). E2F8 is an atypical member of the E2F family of transcription factors (Maiti et al., 2005), but recent evidence demonstrates that E2F8 controls proliferation and tumorigenicity in hepatocellular carcinoma cell lines and is required for the growth of lung cancer cells (Deng et al., 2010; Park et al., 2015). The upregulation of the SKP2 oncogene is of particular interest as high SKP2 expression is observed in high-risk NB (Westermann et al., 2007). SKP2 is an essential component of the ubiquitin proteasome system and promotes proliferation largely by degradation of the cyclin-dependent kinase inhibitor p27 (Carrano et al., 1999; Nakayama et al., 2004; Hershko, 2008). The onset of p27 expression during sympathetic neurogenesis correlates with neuroblast cellcycle exit and p27 overexpression blocks neuroblast proliferation, which together imply that p27 is involved in the termination of sympathetic neurogenesis (Reiff et al., 2010; Holzmann et al., 2015). Thus, it was of interest to test the function of SKP2 in $M Y C N / A L K^{F 1174 L}$ cells using the SKP2-inhibitor C1, which specifically interferes with SKP2-p27 interaction and prevents p27 degradation (Wu et al., 2012). The complete block of neuroblast proliferation observed at 8 dic upon $\mathrm{C} 1$ addition between 5 and 8 dic (Fig. 8B) demonstrates an essential role of SKP2 in sympathetic neuroblast proliferation, downstream of MYCN and activated ALK.

The specific functions of MYCN in the $A L K^{F 1174 L}$ context must also include pathways linking RET expression to sympathetic neuroblast proliferation. The tyrosine kinase receptor RET is upregulated in $A L K^{F 1178 L} / M Y C N$ NB compared with TH-MYCN mouse NB and is important for tumor growth, as shown by the effects of the RET inhibitor vandetanib (Cazes et al., 2014). Interestingly, we now observed that RET levels are not increased in $A L K^{F 1174 L} / M Y C N$ cultures compared with $A L K^{F 1174 L}$ neuron cultures (Fig. $8 A$ ) but in contrast are elevated in both $A L K^{F 1174 L} / M Y C N$ and $A L K^{F 1174 L}$ compared with MYCN cultures (Fig. 6; data not shown). This implies that RET induced by activated ALK acquires a function in neuroblast proliferation only in 
combination with MYCN. Indeed, when $A L K^{F 1174 L} / M Y C N$ cultures were treated with the RET-inhibitor vandetanib between 5 and 8 dic, the percentage of EdUlabeled neuroblasts was reduced from $43 \pm 4 \%$ to $26 \pm 6 \%$ (mean \pm SEM; $n=$ $\left.3 ;{ }^{\star} p<0.05\right)$.

\section{Long-term maintenance of} ALK/MYCN-expressing neuroblasts $A L K^{F 1174 L}$-induced sympathetic neurons can be maintained for several weeks in culture (Fig. 5D), whereas the number of MYCN-expressing or MYC-expressing neuroblasts decreases despite continued cell proliferation (Fig. 3). The coexpression of $A L K^{F 1174 L}$ and $M Y C N$ increases survival compared with $M Y C$-expressing or MYCN-expressing cells, but there is only a small net increase in neuroblast numbers in MYCN/ALK ${ }^{\mathrm{F} 1174 \mathrm{~L}}$ cultures at 8 dic (Fig. 7C). This is most likely due to MYC protein-induced apoptosis, which may be reflected by increased $B I D$ expression (Fig. 8A).

As the extent of MYC protein-induced apoptosis is strongly dependent on the presence of extracellular survival factors (Lowe et al., 2004), we took advantage of our previous observation that survival of avian sympathetic neuroblasts infected by the MYC-expressing myelocytomatosis virus (MC29) is improved by the addition of CEE, a classical component of avian neural crest culture media (Haltmeier and Rohrer, 1990). We now demonstrate a strong increase in the number of $A L K / M Y C N$ neuroblasts at $8 \mathrm{dic}$ in the presence of $\mathrm{CEE}$ (Fig. 9). As ganglion non-neuronal cells also proliferate under these conditions, it remains unclear whether increased survival is a direct effect of CEE components on sympathetic neuroblasts or caused by signals from non-neuronal cells. Irrespective of the underlying mechanism, this result demonstrates that survival of $A L K^{F 1178 L} / M Y C N$-expressing cells depends on environmental signals. Development of NB from $A L K^{F 1178 L} /$ $M Y C N$-coexpressing neuroblasts may also depend on the presence of extrinsic survival signals.

\section{Discussion}

NB can be induced in mouse sympathetic ganglia and adrenals by forced expression of MYCN or activated ALK. MYCN/ALK coexpression results in earlier onset and increased penetrance of tumor formation, but the mechanisms that underlie this cooperation are incompletely understood. Using cultures of embryonic chick sympathetic neuroblasts, we now demonstrate

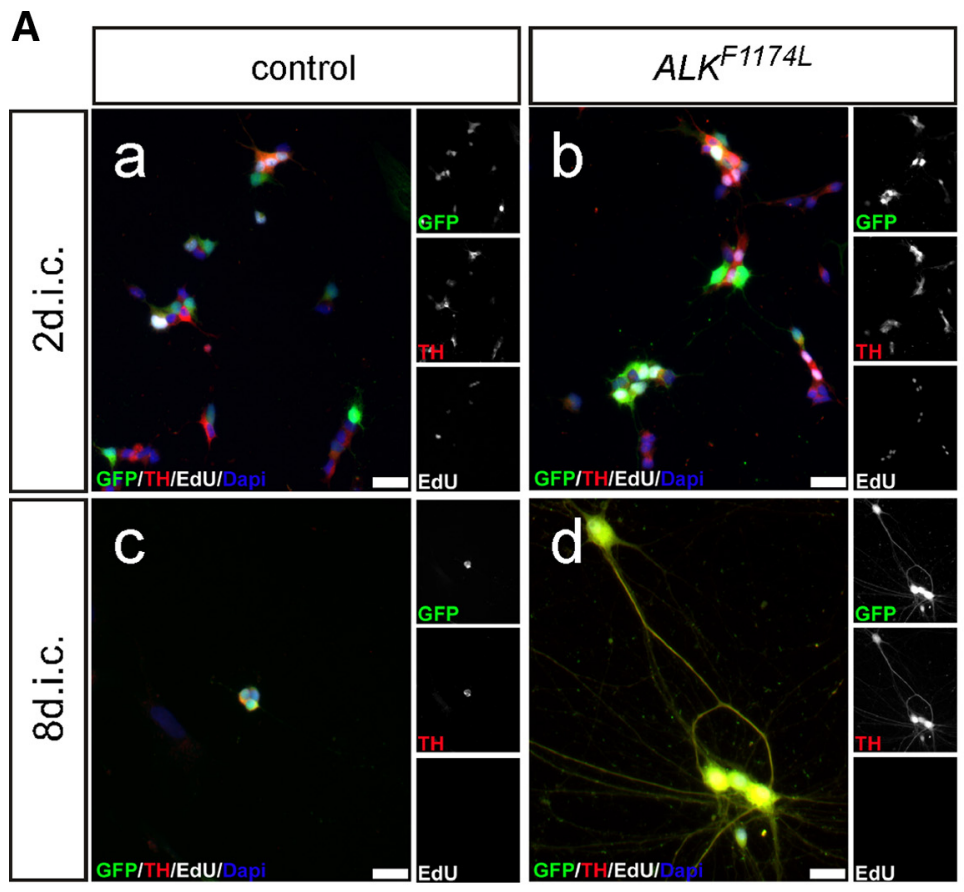

B

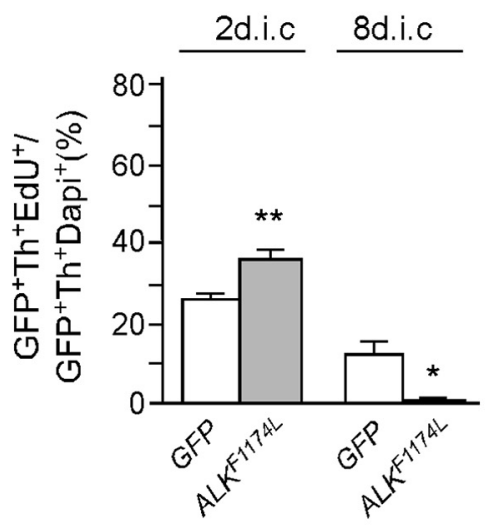

D
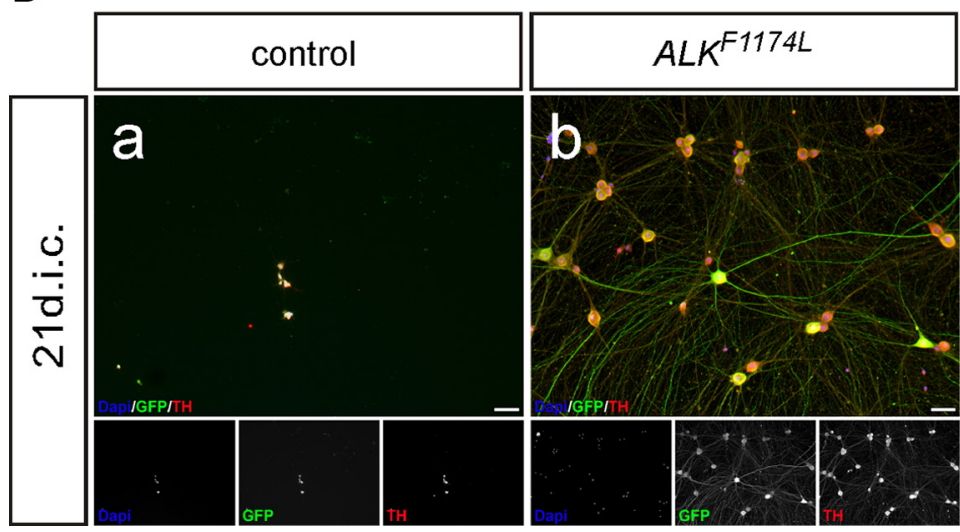

Figure 5. Effects of activated ALK on cultured chick sympathetic neuroblasts. $A, E 7$ sympathetic ganglion cells were transfected with expression vectors for GFP (control; $\boldsymbol{A a}, \boldsymbol{A c}$ ) or GFP and $A L K^{F 1174 L}(\boldsymbol{A} \boldsymbol{b}, \boldsymbol{A d})$ and analyzed by GFP/Th/EdU-triple immunostaining after 2 $(\boldsymbol{A} \boldsymbol{a}, \boldsymbol{A b})$ and $8 \mathrm{dic}(\boldsymbol{A c}, \boldsymbol{A d})$ for proliferating EdU-incorporating neuroblasts. Note the neuronal morphology induced by activated ALK signaling at 8 dic ( $\boldsymbol{A} \boldsymbol{d})$. B, Quantification reveals a significantly increased proliferation of $A L K^{F 1174 L}$-expressing neuroblasts compared with GFP controls at 2 dic (mean $\pm S E M ; n \geq 6 ;{ }^{* *} p<0.01$ ). At 8 dic, in contrast, proliferating neuroblasts are absent (mean \pm SEM; $n \geq 6$; ${ }^{*} p<0.05$; unpaired two-tailed $t$ test). $C$, ALK ${ }^{F 1774 L}$ expression does not affect neuroblast number at 2 dic but results in a strongly increased survival of Alk-induced neurons (mean \pm SEM; $n \geq 4 ;{ }^{* *} p<0.01$ ). D, Sympathetic neurons induced by activated ALK survive for extended culture periods (3 weeks; $\boldsymbol{D} \boldsymbol{b}$ ), in contrast to GFP-transfected control neuroblasts (Da). Please note the large neuron cell bodies and extensive neurite network of ALK-induced sympathetic neurons. Scale bar, $50 \mu \mathrm{m}$. 


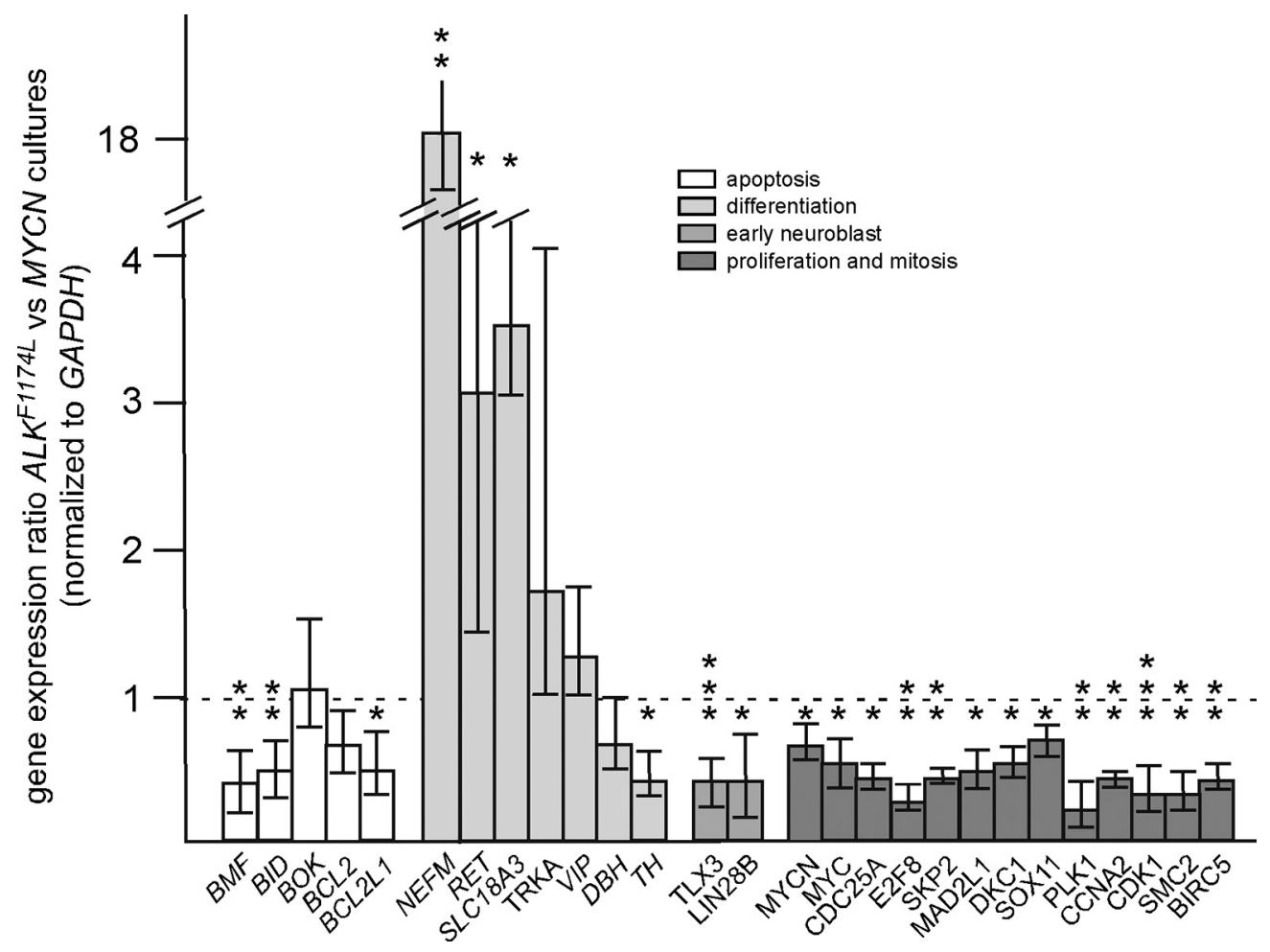

Figure 6. Effects of ALK signaling on the expression of marker genes for apoptosis, neuron differentiation, early sympathetic neuroblasts, proliferation, and mitosis analyzed by qRT-PCR. Differential gene expression between $A L K^{F 1174 L}$-transfected and MYCN-transfected $8 \mathrm{~d}$ cultures analyzed by qRT-PCR (mean $\pm S E ;{ }^{*} p<0.05$; ${ }^{* *} p<0.01$; ${ }^{* * *} p<0.001$; statistical analysis by relative expression software tool). Note that the MYCN bar corresponds to endogenous chicken MYCN and not from the transfected gene.

that (1) MYC or MYCN overexpression alone increases proliferation but not long-term survival; (2) neuroblasts respond to $A L K^{F 1174 L}$ signaling by a transient increase in proliferation followed by cell-cycle withdrawal, differentiation, and long-term survival of $A L K^{F 1174 L}$-induced sympathetic neurons, whereas (3) overexpression of both $A L K^{F 1174 L}$ and $M Y C N$ results in neuroblasts, which proliferate, are more differentiated, and show improved survival compared with neuroblasts expressing MYCN only; (4) E2F8, DKC1, CCNA2, and the ubiquitin ligase subunit SKP2, which targets $\mathrm{p} 27$ for degradation, are induced by $M Y C N$ under conditions of activated ALK signaling; and (5) SKP2 inhibition reduces proliferation of MYCN/ALK ${ }^{F 1174 L}$ cells. Together, our data provide a novel view of how MYCN/ALK may cooperate and implicate SKP2 upregulation as an important early step preventing terminal cell-cycle withdrawal and thus promoting NB formation.

\section{Expression and function of MYC genes during neurogenesis in sympathetic ganglia}

The relative expression of MYC genes differs strongly between different parts of the nervous system (Stanton et al., 1992; Martins et al., 2008; Domínguez-Frutos et al., 2011). MYCN knockout and targeted deletion in neuronal progenitors result in decreased brain size and reduced sensory ganglia (Charron et al., 1992; Knoepfler et al., 2002), whereas conditional deletion of $M Y C$ has only a minor effect (Hatton et al., 2006). The relative expression and function of MYC and MYCN in developing sympathetic ganglia has not been investigated, but the small reduction of ganglion size in MYCN knock-out mice (Sawai et al., 1993) suggests a function for other MYC family members. The present analysis shows that $M Y C$ is expressed at much higher levels than $M Y C N$ and is essential for sympathetic neuroblast proliferation, whereas $M Y C N$ knockdown has only a small effect. Together, these results indicate that endogenous proliferation of neuroblasts depends mainly on MYC. The importance of $M Y C N$ in NB generation does not reflect its developmental function but is related to $M Y C N$ gene amplification and redundant biological effects of MYCN and MYC (Malynn et al., 2000).

\section{Interference with MYC gene expression by JQ1-mediated BET protein inhibition}

Inhibition of BET bromodomain proteins by JQ1 treatment interferes with the transcription of MYC and MYCN genes (Delmore et al., 2011; Puissant et al., 2013). NB cell lines with MYCN amplification are very sensitive to JQ1, which was explained by BRD4-dependent MYCN transcription (Puissant et al., 2013). Recent studies suggest that JQ1 causes a preferential loss of BRD4 and transcription from super-enhancers controlling both $\operatorname{MYC}(N)$ and $\operatorname{MYC}(N)$ target genes (Lovén et al., 2013; Henssen et al., 2016). The complete inhibition of sympathetic neuroblast proliferation by JQ1 treatment, in contrast to findings with NB cell lines with normal MYCN expression (Puissant et al., 2013), demonstrates a strong difference between neuroblasts and NB cell lines with implications for clinical treatment. In contrast to other cells (Delmore et al., 2011), JQ1 treatment does not completely block MYC and MYCN expression in sympathetic neuroblasts. Thus, inhibition of sympathetic neuroblast proliferation may in addition reflect effects of JQ1 on MYCN targets (Henssen et al., 2016) and/or dependence on the activity of superenhancers controlling master genes of sympathetic neuron identity (e.g., PHOX2B, HAND2; Whyte et al., 2013), all of which also affect neuroblast proliferation (Rohrer, 2011). Notably, the proliferation of ganglion non-neuronal cells is not affected by JQ1, 

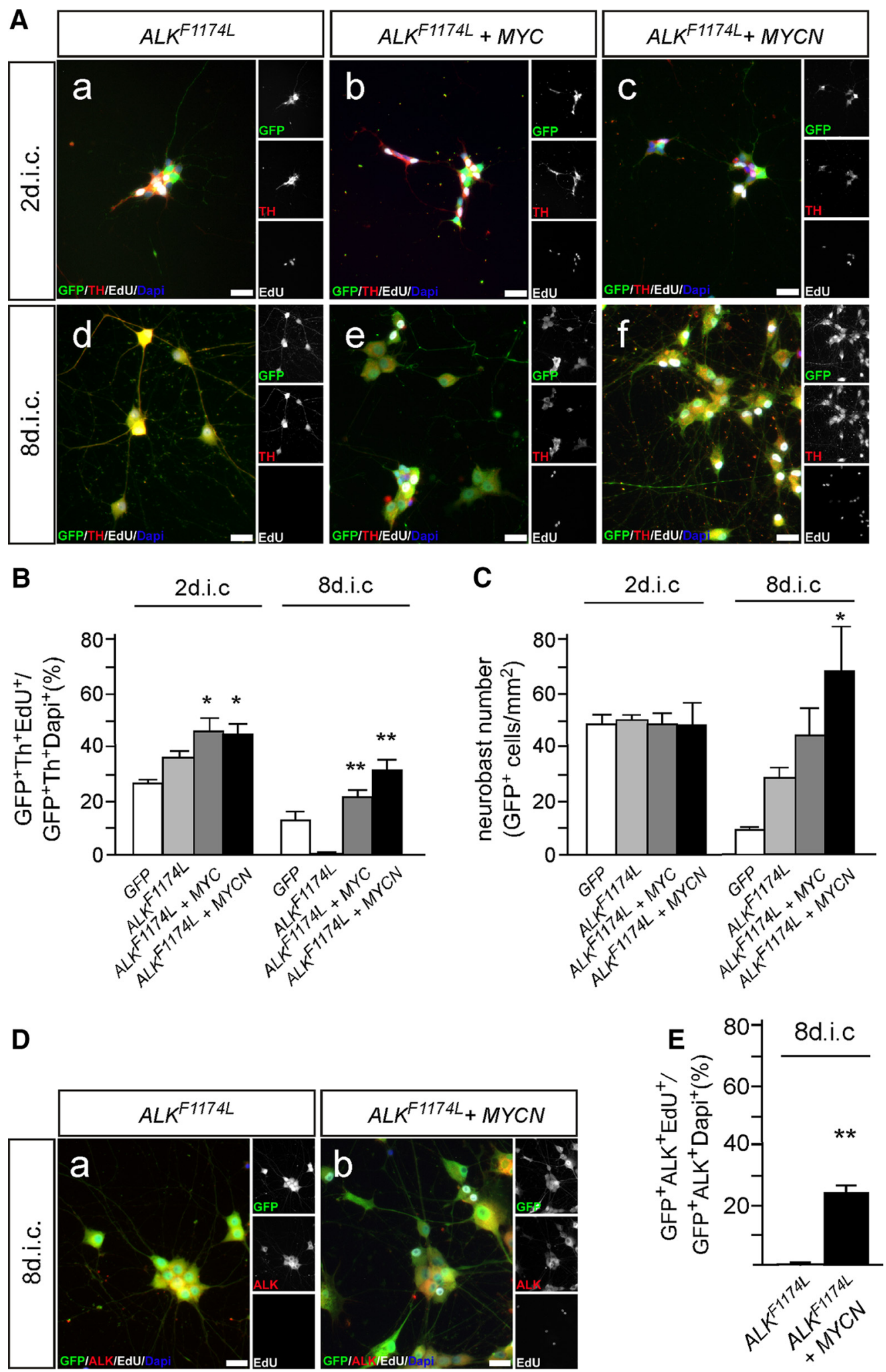

Figure 7. Coexpression of $A L K^{F 1174 L}$ and MYC proteins supports neuroblast proliferation and survival. $A$, E7 sympathetic ganglion cells were transfected with expression vectors for GFP and

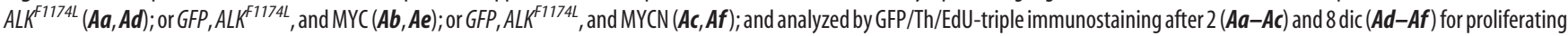
EdU-incorporating neuroblasts. Note that proliferating ALK/MYC cells $(\boldsymbol{A e}, \boldsymbol{A} \boldsymbol{f})$ are smaller and show a less mature neuronal morphology compared with neurons induced by activated ALK signaling at $8 \mathrm{dic}(\boldsymbol{A d})$. B, Quantification reveals a significantly increased proliferation of MYC/ALK $K^{F 1174 L}$-expressing and MYC/ALK ${ }^{F 1174 L}$-expressing neuroblasts compared with $A L K^{F 1174 L}$ neuroblasts at 2 dic (mean $\pm S E M ; n \geq 6 ;{ }^{*} p<0.05$ ). At 8 dic, proliferating neuroblasts are present in transfected cultures but absent in $A L K^{F 1174 L}$ neuroblasts (mean $\pm S E M ; n \geq 6$; ${ }^{* *} p<0.01 ;$ unpaired two-tailed $t$ test). C, The combined MYCN/ALK ${ }^{F 1744}$ expression does not affect neuroblast numbers at 2 dic, but results in a strongly increased neuron number at 8 dic compared with $A L K^{F 1174 L}$ (mean \pm SEM; $n \geq 4 ;{ }^{*} p<0.05$ ). Data for GFP-transfected controls are included for comparison from Figure $5 B, C$. D. Proliferation of sympathetic neuroblasts transfected with expression vectors for GFP and $A L K^{F 1174 L}(\boldsymbol{D a})$; or for GFP, $A L K^{F 1174 L}$, and MYCN (Db); and analyzed by GFP/ALK/EdU-triple immunostaining after 8 dic for proliferating EdU-incorporating $\mathrm{ALK}^{+}{ }^{+}$neuroblasts. $\boldsymbol{E}_{\text {, Quantification reveals }}$ increased proliferation of $\mathrm{ALK}^{+}$neuroblasts in MYCN/ALK ${ }^{F 174 L}$ compared with $A L K^{F 174 L L}$ cultures (mean \pm SEM; $n \geq 3 ;{ }^{* *} p<0.01$ ). 


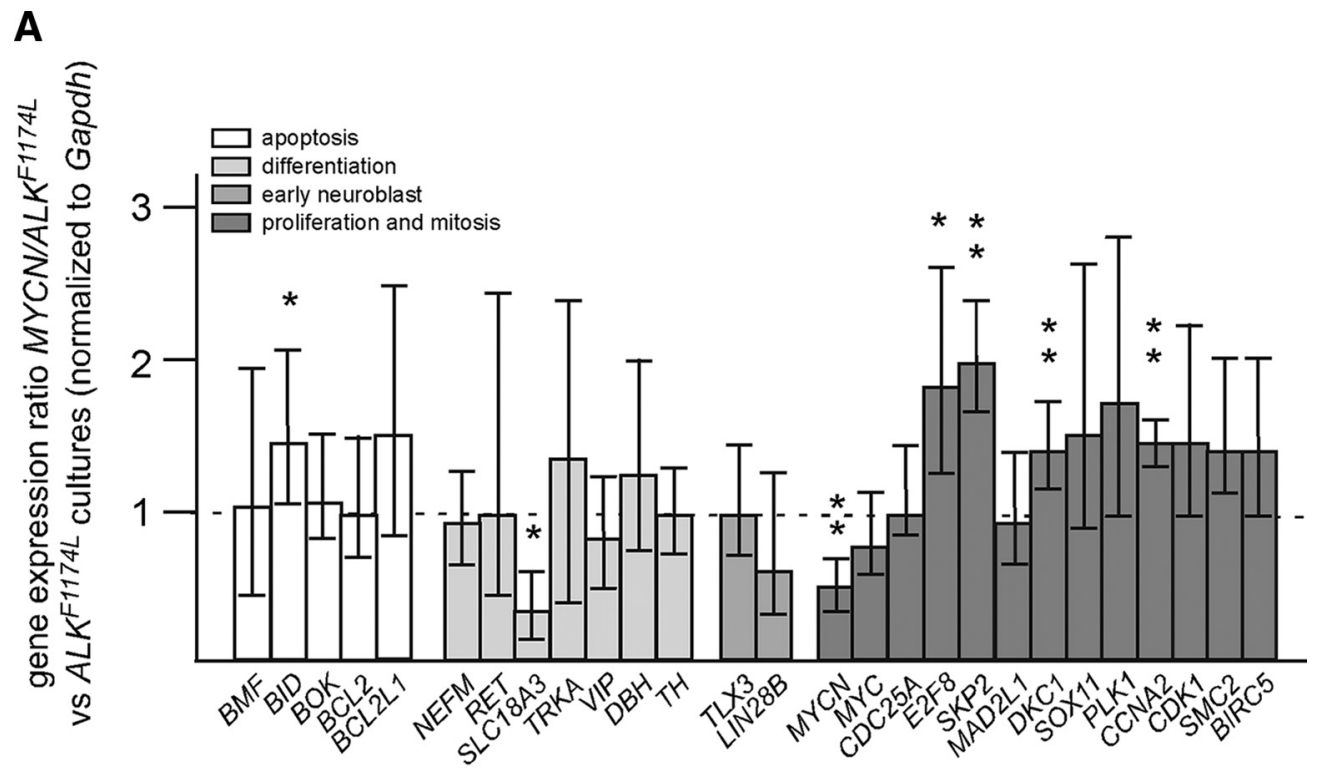

B

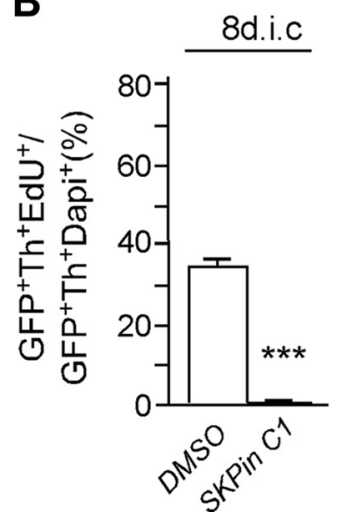

Figure 8. Effects of combined MYCN/ALK signaling on the expression of marker genes for apoptosis, neuron differentiation, early sympathetic neuroblasts, proliferation, and mitosis analyzed by qRT-PCR; effects of SKP2 inhibition on the proliferation of MYCN/ALK $K^{F 174 L}$ neuroblasts. A, Differential gene expression between MYCN/ALK ${ }^{F 1174 L}$-transfected and $A L K^{F 1174 L}$ transfected $8 \mathrm{~d}$ cultures analyzed by qRT-PCR (mean $\pm \mathrm{SE} ;{ }^{*} p<0.05 ;{ }^{* *} p<0.01$; statistical analysis by relative expression software tool). $B$, E7 sympathetic ganglion cells were transfected with expression vectors for GFP, ALK ${ }^{F 174 L}$, and MYCN. Cultures were supplemented at 5 dic with $10 \mu \mathrm{M} \mathrm{SKP2} \mathrm{inhibitor} \mathrm{SKPin} \mathrm{C1} \mathrm{in} \mathrm{DMSO} \mathrm{or} \mathrm{with} \mathrm{DMSO} \mathrm{alone} \mathrm{and} \mathrm{analyzed} \mathrm{by}$ GFP/Th/EdU triple immunostaining after 8 dic for the percentage of EdU-labeled proliferating MYCN/ALK ${ }^{F 174 L}$ neuroblasts. SKP2 inhibition resulted in a virtually complete proliferation block (mean $\pm \mathrm{SEM} ; n=3 ;{ }^{* * *} p<0.001$ ).

indicating different BRD4-activated enhancers in neuroblasts and glia.

\section{Sympathetic neuroblast propagation by forced MYCN and MYC expression}

The initial steps in NB development are not well understood, as illustrated by the finding that targeted MYCN expression in E10.5 mouse sympathetic neuroblasts does not increase proliferation until postnatal stages (Hansford et al., 2004; Alam et al., 2009; Althoff et al., 2015). We now demonstrate that continued overexpression of MYC or MYCN in chick sympathetic neuroblasts results in a strong increase in the percentage of proliferating cells. $M Y C N$ overexpression also increases neuroblast proliferation in vivo. The difference between $M Y C N$-transfected chick neuroblasts and embryonic sympathetic ganglia of $M Y C N$-expressing mice may be due to higher MYCN expression levels in transfected neuroblasts using the strong $\mathrm{CAG}$ promotor. Increased proliferation of $M Y C(N)$-expressing neuroblasts does not, however, lead to a net increase in neuroblast number, which is explained by increased apoptosis. The apoptotic loss of $M Y C(N)$-expressing cells may either reflect the poor neuroblast survival also observed in controls or the induction of antioncogenic programs that lead to senescence and apoptosis (Lowe et al., 2004).

Proliferation and differentiation of sympathetic neuroblasts: alternative fates induced by activated ALK signaling

Although different tyrosine kinase receptors activate a common set of signal transduction pathways, distinct cellular effects are elicited by each receptor. For example, proliferation or differentiation is elicited in PC12 cells by EGF and NGF, respectively, correlating with transient and sustained activation of the MAPK signal cascade (Marshall, 1995). Here, we observed that $A L K^{F 174 L}$ first increases proliferation and subsequently induces cell-cycle exit, differentiation, and neuron survival. These results may be explained by a maturation of sympathetic neuroblasts with time, leading to a different interpretation of ALK signaling in young versus more mature neuroblasts. This would be in agreement with the results in the Ki-Alk mouse where sympathetic neuroblasts show increased proliferation but eventually leave the cell cycle and differenti- 

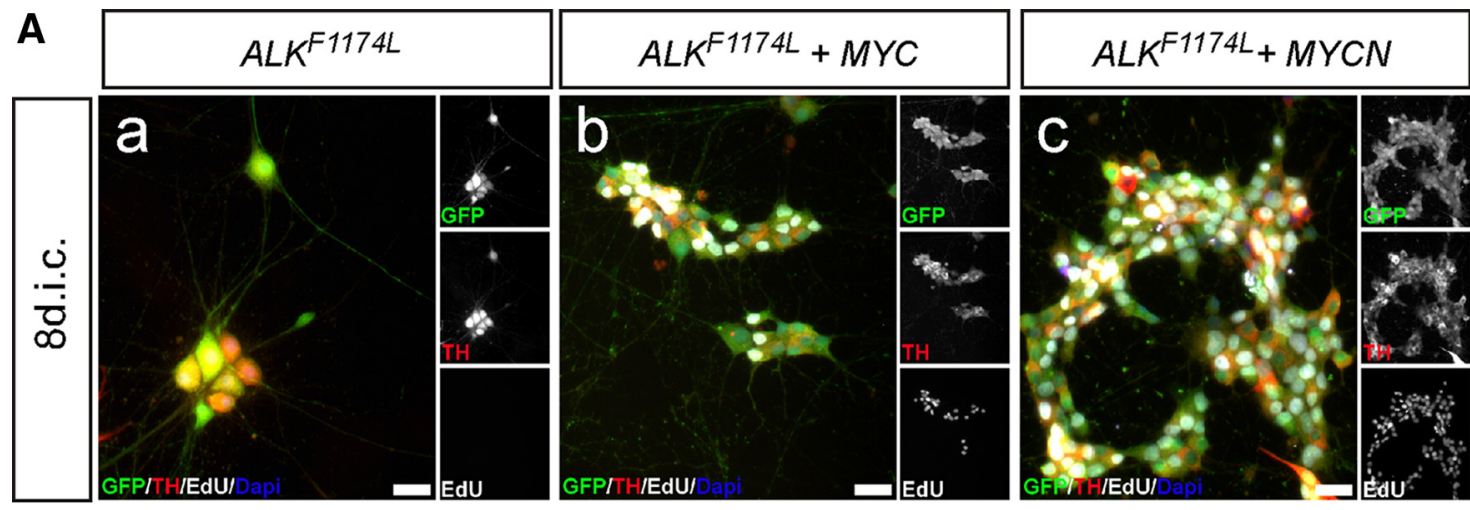

B

\section{2d.i.c}

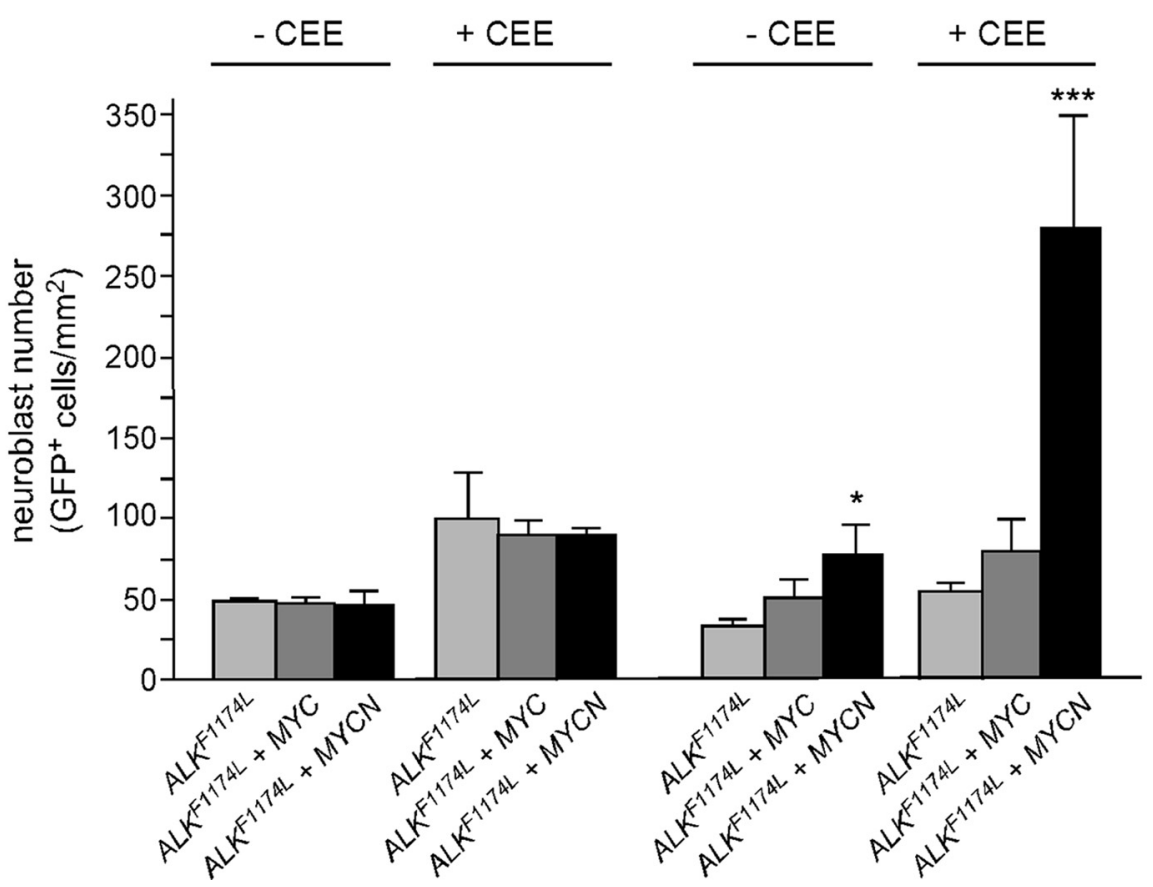

Figure 9. MYCN/ALK ${ }^{F 1174 L}$-transfected cells can be expanded in the presence of CEE. A, E7 sympathetic ganglion cells were transfected with expression vectors for GFP and ALK ${ }^{F 1174 L}$ (Aa); or GFP, $A L K^{F 1174 L}$, and MYC $(\boldsymbol{A} \boldsymbol{b})$; or GFP, $A L K^{F 1174 L}$, and MYCN $(\boldsymbol{A c})$; and analyzed by GFP/Th/EdU triple immunostaining after 8 dic in the presence or absence of 2\% CEE for proliferating EdU-incorporating

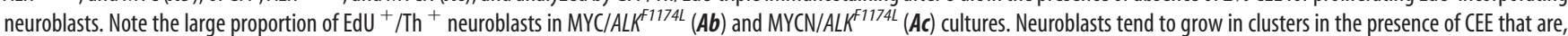
however, much sparser in MYC/ALKF ${ }^{F 174 L}$ compared with MYCN/ALKF1174L cultures. Scale bar, $20 \mu \mathrm{m}$. B. Combined MYC/ALK ${ }^{F 1174 L}$ and MYCN/ALK $K^{F 174 L}$ expression does not affect neuroblast number at 2 dic but MYCN/ALKF ${ }^{F 174 L}$ increases the number of surviving cells compared with $2 \mathrm{~d}$ cultures (mean $\pm S E M ; n \geq 4 ;{ }^{*} p<0.05$ ). Data from cultures without CEE are included for comparison with Figure $7 C$.

ate (Cazes et al., 2014). An alternative explanation would be that an initially low ALK expression is unable to induce differentiation. This would be reminiscent to the finding that PC12 cells with low numbers of TrkA receptors do not differentiate in response to NGF (Schlessinger and Bar-Sagi, 1994). Proliferation effects may also be due to ALK located mainly in ER and Golgi (Mazot et al., 2011) in contrast to ALK located in the plasma membrane, where ALK elicits differentiation (Gouzi et al., 2005). Regardless of these explanations, our data indicate that cell-cycle exit and differentiation is the final result of activated ALK in cultured sympathetic neuroblasts. In contrast to our in vitro findings, expression of activated ALK in mouse sympathoadrenal cells leads to NB formation (Heukamp et al., 2012). The low penetrance and late onset of tumor formation suggests, however, that tumor initiation depends on additional genomic aberrations identified in these tumors (Heukamp et al., 2012).

\section{ALK-induced sympathetic neuron differentiation} and survival

Cell-cycle withdrawal and morphological differentiation in response to $A L K^{F 1174 L}$ is reflected by decreased expression of genes involved in cell-cycle progression and mitosis (e.g., CDC25A, CCNA2, CDK1, MAD2L1, and SMC2), upregulation of the generic neuron differentiation gene NEFM, and low expression of early neuroblast markers TLX3 and LIN28B (Huang et al., 2013; Hennchen et al., 2015). Upregulated RET has no proliferative function in $A L K^{F 1174 L}$-induced sympathetic neurons, in contrast to $M Y C N / A L K^{F 1174 L}$ neuroblasts and MYCN/ALK-induced mouse NB (Cazes et al., 2014; Lambertz et al., 2015). The longterm survival of $A L K^{F 1174 L}$-induced neurons is surprising as sympathetic neuron death is tightly controlled by NGF/TRKA signaling with TRKA acting as an apoptosis-inducing dependence receptor (Nikoletopoulou et al., 2010). We propose that survival is enabled by the reduced expression of proapoptotic 
$\mathrm{BH} 3$-only genes $B M F$ and $B I D$ leading to the net dominance of antiapoptotic proteins.

\section{Cooperative effects of MYCN and activated ALK in sympathetic neuroblasts}

Neuroblasts coexpressing $M Y C(N)$ and $A L K^{F 1174 L}$ continue to proliferate, whereas all $A L K^{F 1174 L}$-expressing cells have left the cell cycle at 8 dic. Maintained proliferation results only in a small increase in MYCN/ALK ${ }^{F 1174 L}$ cells, suggesting that ALK signaling may not be sufficient to interfere completely with the proapoptotic effects of forced $M Y C(N)$ expression as indicated by increased BID levels. Survival of MYCN/ALK $K^{F 1174 L}$-expressing cells is, however, maintained in CEE-supplemented cultures, leading to expansion and net increase of MYCN/ALK ${ }^{F 1174 L}$ cells. Unexpectedly, this survival effect is selective for $M Y C N / A L K^{F 1174 L}$ cells, raising the question whether MYC/ALK cooperation may be sufficient to induce NB.

Interestingly, the expression of the majority of genes analyzed by qRT-PCR does not differ between MYCN/ALK ${ }^{F 1174 L}$ neuroblasts and $A L K^{F 1174 L}$-expressing neurons, which may reflect their differentiated characteristics. From the analyzed genes involved in the cell cycle and mitosis, only SKP2, DKC1, CCNA2, and E2F8 are upregulated. Of particular interest is the MYCN-induced upregulation of the SKP2 oncogene (Hershko, 2008) and the reduction of MYCN/ALK $K^{F 1174 L}$ neuroblast proliferation by SKP2 inhibition. SKP2 is a direct MYCN and MYC target and the main oncogenic mechanism of SKP2 is attributed to the degradation of the CDK inhibitor p27 (Carrano et al., 1999; Sutterlüty et al., 1999; Bretones et al., 2011; Evans et al., 2015). High SKP2 expression is characteristic for high-risk NB and is inversely correlated with p27 expression (Westermann et al., 2007; Chu et al., 2008). P27 is induced when sympathetic neuroblasts leave the cell cycle and p27 overexpression blocks cell cycle progression (Reiff et al., 2010; Holzmann et al., 2015). Together, these results suggest that SKP2 upregulation may be an essential early step induced by MYCN/ALK ${ }^{\mathrm{F} 1174 \mathrm{~L}}$ cooperation to maintain neuroblast proliferation during NB development.

\section{References}

Alam G, Cui H, Shi H, Yang L, Ding J, Mao L, Maltese WA, Ding HF (2009) MYCN promotes the expansion of Phox2B-positive neuronal progenitors to drive neuroblastoma development. Am J Pathol 175:856-866. CrossRef Medline

Althoff K, Beckers A, Bell E, Nortmeyer M, Thor T, Sprüssel A, Lindner S, De Preter K, Florin A, Heukamp LC, Klein-Hitpass L, Astrahantseff K, Kumps C, Speleman F, Eggert A, Westermann F, Schramm A, Schulte JH (2015) A Cre-conditional MYCN-driven neuroblastoma mouse model as an improved tool for preclinical studies. Oncogene 34:3357-3368. CrossRef Medline

Bell E, Lunec J, Tweddle DA (2007) Cell cycle regulation targets of MYCN identified by gene expression microarrays. Cell Cycle 6:1249-1256. CrossRef Medline

Bell E, Chen L, Liu T, Marshall GM, Lunec J, Tweddle DA (2010) MYCN oncoprotein targets and their therapeutic potential. Cancer Lett 293: 144-157. CrossRef Medline

Berry T, Luther W, Bhatnagar N, Jamin Y, Poon E, Sanda T, Pei D, Sharma B, Vetharoy WR, Hallsworth A, Ahmad Z, Barker K, Moreau L, Webber H, Wang W, Liu Q, Perez-Atayde A, Rodig S, Cheung NK, Raynaud F, et al (2012) The ALK(F1174L) mutation potentiates the oncogenic activity of MYCN in neuroblastoma. Cancer Cell 22:117-130. CrossRef Medline

Bonnefoy E, Ferrara P, Rohrer H, Gros F, Thibault J (1988) Role of the $\mathrm{N}$-terminus of rat pheochromocytoma tyrosine hydroxylase in the regulation of the enzyme's activity. Eur J Biochem 174:685-690. CrossRef Medline

Breit S, Schwab M (1989) Suppression of MYC by high expression of NMYC in human neuroblastoma cells. J Neurosci Res 24:21-28. Medline

Bretones G, Acosta JC, Caraballo JM, Ferrandiz N, Gómez-Casares MT, Al- bajar M, Blanco R, Ruiz P, Hung WC, Albero MP, Perez-Roger I, León J (2011) SKP2 oncogene is a direct MYC target gene and MYC downregulates p27(KIP1) through SKP2 in human leukemia cells. J Biol Chem 286:9815-9825. CrossRef Medline

Brodeur GM, Seeger RC, Schwab M, Varmus HE, Bishop JM (1984) Amplification of $\mathrm{N}$-myc in untreated human neuroblastomas correlates with advanced disease stage. Science 224:1121-1124. CrossRef Medline

Cadiñanos J, Bradley A (2007) Generation of an inducible and optimized piggyBac transposon system. Nucleic Acids Res 35:e87. CrossRef Medline

Carrano AC, Eytan E, Hershko A, Pagano M (1999) SKP2 is required for ubiquitin-mediated degradation of the CDK inhibitor p27. Nat Cell Biol 1:193-199. CrossRef Medline

Cazes A, Lopez-Delisle L, Tsarovina K, Pierre-Eugène C, De Preter K, Peuchmaur M, Nicolas A, Provost C, Louis-Brennetot C, Daveau R, Kumps C, Cascone I, Schleiermacher G, Prignon A, Speleman F, Rohrer H, Delattre O, Janoueix-Lerosey I (2014) Activated Alk triggers prolonged neurogenesis and Ret upregulation providing a therapeutic target in ALKmutated neuroblastoma. Oncotarget 5:2688-2702. CrossRef Medline

Charron J, Malynn BA, Fisher P, Stewart V, Jeannotte L, Goff SP, Robertson EJ, Alt FW (1992) Embryonic lethality in mice homozygous for a targeted disruption of the N-myc gene. Genes Dev 6:2248-2257. CrossRef Medline

Chen Y, Takita J, Choi YL, Kato M, Ohira M, Sanada M, Wang L, Soda M, Kikuchi A, Igarashi T, Nakagawara A, Hayashi Y, Mano H, Ogawa S (2008) Oncogenic mutations of ALK kinase in neuroblastoma. Nature 455:971-974. CrossRef Medline

Chu IM, Hengst L, Slingerland JM (2008) The Cdk inhibitor p27 in human cancer: prognostic potential and relevance to anticancer therapy. Nat Rev Cancer 8:253-267. CrossRef Medline

De Brouwer S, De Preter K, Kumps C, Zabrocki P, Porcu M, Westerhout EM, Lakeman A, Vandesompele J, Hoebeeck J, Van Maerken T, De Paepe A, Laureys G, Schulte JH, Schramm A, Van Den Broecke C, Vermeulen J, Van Roy N, Beiske K, Renard M, Noguera R, et al. (2010) Meta-analysis of neuroblastomas reveals a skewed ALK mutation spectrum in tumors with MYCN amplification. Clin Cancer Res 16:4353-4362. CrossRef Medline

Delmore JE, Issa GC, Lemieux ME, Rahl PB, Shi J, Jacobs HM, Kastritis E, Gilpatrick T, Paranal RM, Qi J, Chesi M, Schinzel AC, McKeown MR, Heffernan TP, *akoc CR, Bergsagel PL, Ghobrial IM, Richardson PG, Young RA, Hahn WC, et al. (2011) BET bromodomain inhibition as a therapeutic strategy to target c-Myc. Cell 146:904-917. CrossRef Medline

Deng Q, Wang Q, Zong WY, Zheng DL, Wen YX, Wang KS, Teng XM, Zhang X, Huang J, Han ZG (2010) E2F8 contributes to human hepatocellular carcinoma via regulating cell proliferation. Cancer Res 70: 782-791. CrossRef Medline

Ding S, Wu X, Li G, Han M, Zhuang Y, Xu T (2005) Efficient transposition of the piggyBac (PB) transposon in mammalian cells and mice. Cell 122: 473-483. CrossRef Medline

Domínguez-Frutos E, López-Hernández I, Vendrell V, Neves J, Gallozzi M, Gutsche K, Quintana L, Sharpe J, Knoepfler PS, Eisenman RN, Trumpp A, Giráldez F, Schimmang T (2011) N-myc controls proliferation, morphogenesis, and patterning of the inner ear. J Neurosci 31:7178-7189. CrossRef Medline

Evans L, Chen L, Milazzo G, Gherardi S, Perini G, Willmore E, Newell DR, Tweddle DA (2015) SKP2 is a direct transcriptional target of MYCN and a potential therapeutic target in neuroblastoma. Cancer Lett 363:37-45. CrossRef Medline

George RE, Sanda T, Hanna M, Fröhling S, Luther W 2nd, Zhang J, Ahn Y, Zhou W, London WB, McGrady P, Xue L, Zozulya S, Gregor VE, Webb TR, Gray NS, Gilliland DG, Diller L, Greulich H, Morris SW, Meyerson $\mathrm{M}$, et al. (2008) Activating mutations in ALK provide a therapeutic target in neuroblastoma. Nature 455:975-978. CrossRef Medline

Gouzi JY, Moog-Lutz C, Vigny M, Brunet-de Carvalho N (2005) Role of the subcellular localization of ALK tyrosine kinase domain in neuronal differentiation of PC12 cells. J Cell Sci 118:5811-5823. CrossRef Medline

Haltmeier H, Rohrer H (1990) Distinct and different effects of the oncogenes $v$-myc and $v$-src on avian sympathetic neurons: retroviral transfer of $v$ - $m y c$ stimulates neuronal proliferation whereas $v$-src transfer enhances neuronal differentiation. J Cell Biol 110:2087-2098. CrossRef Medline

Hansford LM, Thomas WD, Keating JM, Burkhart CA, Peaston AE, Norris MD, Haber M, Armati PJ, Weiss WA, Marshall GM (2004) Mechanisms of embryonal tumor initiation: distinct roles for $\mathrm{MycN}$ expres- 
sion and MYCN amplification. Proc Natl Acad Sci U S A 101:1266412669. CrossRef Medline

Hatton BA, Knoepfler PS, Kenney AM, Rowitch DH, de Alborán IM, Olson JM, Eisenman RN (2006) N-myc is an essential downstream effector of Shh signaling during both normal and neoplastic cerebellar growth. Cancer Res 66:8655-8661. CrossRef Medline

Hennchen M, Stubbusch J, Abarchan-El Makhfi I, Kramer M, Deller T, Pierre-Eugene C, Janoueix-Lerosey I, Delattre O, Ernsberger U, Schulte JB, Rohrer H (2015) Lin28B and Let-7 in the control of sympathetic neurogenesis and neurblastoma development. J Neurosci 35:1653116544. CrossRef Medline

Henriksen JR, Haug BH, Buechner J, Tømte E, Løkke C, Flaegstad T, Einvik C (2011) Conditional expression of retrovirally delivered anti-MYCN shRNA as an in vitro model system to study neuronal differentiation in MYCN-amplified neuroblastoma. BMC Dev Biol 11:1. CrossRef Medline

Henssen AG, Althoff K, Odersky A, Beckers A, Koche R, Speleman F, Schäfers S, Bell E, Nortmeyer M, Westermann F, De Preter K, Florin A, Heukamp L, Spruessel A, Astrahanseff K, Lindner S, Sadowski N, Schramm A, Astorgues-Xerri L, Riveiro ME, et al. (2016) Targeting MYCN-driven transcription by BET-bromodomain inhibition. Clin Cancer Res 22: 2470-2481. CrossRef Medline

Hershko DD (2008) Oncogenic properties and prognostic implications of the ubiquitin ligase Skp2 in cancer. Cancer 112:1415-1424. CrossRef Medline

Heukamp LC, Thor T, Schramm A, De Preter K, Kumps C, De Wilde B, Odersky A, Peifer M, Lindner S, Spruessel A, Pattyn F, Mestdagh P, Menten B, Kuhfittig-Kulle S, Künkele A, König K, Meder L, Chatterjee S, Ullrich RT, Schulte S, et al. (2012) Targeted expression of mutated ALK induces neuroblastoma in transgenic mice. Sci Transl Med 4:141ra191. CrossRef Medline

Holzmann J, Hennchen M, Rohrer H (2015) Prox1 identifies proliferating neuroblasts and nascent neurons during neurogenesis in sympathetic ganglia. Dev Neurobiol 75:1352-1367. CrossRef Medline

Huang T, Hu J, Wang B, Nie Y, Geng J, Cheng L (2013) Tlx3 controls cholinergic transmitter and Peptide phenotypes in a subset of prenatal sympathetic neurons. J Neurosci 33:10667-10675. CrossRef Medline

Janoueix-Lerosey I, Lequin D, Brugières L, Ribeiro A, de Pontual L, Combaret V, Raynal V, Puisieux A, Schleiermacher G, Pierron G, Valteau-Couanet D, Frebourg T, Michon J, Lyonnet S, Amiel J, Delattre O (2008) Somatic and germline activating mutations of the ALK kinase receptor in neuroblastoma. Nature 455:967-970. CrossRef Medline

Kaltezioti V, Kouroupi G, Oikonomaki M, Mantouvalou E, Stergiopoulos A, Charonis A, Rohrer H, Matsas R, Politis PK (2010) Proxl regulates the notch1-mediated inhibition of neurogenesis. PLoS Biol 8:e1000565. CrossRef Medline

Knoepfler PS, Cheng PF, Eisenman RN (2002) N-myc is essential during neurogenesis for the rapid expansion of progenitor cell populations and the inhibition of neuronal differentiation. Genes Dev 16:2699-2712. CrossRef Medline

Lambertz I, Kumps C, Claeys S, Lindner S, Beckers A, Janssens E, Carter DR, Cazes A, Cheung BB, De Mariano M, De Bondt A, De Brouwer S, Delattre O, Gibbons J, Janoueix-Lerosey I, Laureys G, Liang C, Marchall GM, Porcu M, Takita J, et al. (2015) Upregulation of MAPK negative feedback regulators and RET in mutant ALK neuroblastoma: implications for targeted treatment. Clin Cancer Res 21:3327-3339. CrossRef Medline

Lovén J, Hoke HA, Lin CY, Lau A, Orlando DA, Vakoc CR, Bradner JE, Lee TI, Young RA (2013) Selective inhibition of tumor oncogenes by disruption of super-enhancers. Cell 153:320-334. CrossRef Medline

Lowe SW, Cepero E, Evan G (2004) Intrinsic tumour suppression. Nature 432:307-315. CrossRef Medline

Lu Y, Lin C, Wang X (2009) PiggyBac transgenic strategies in the developing chicken spinal cord. Nucleic Acids Res 37:e141. CrossRef Medline

Luo Q, Li J, Cenkci B, Kretzner L (2004) Autorepression of c-myc requires both initiator and E2F-binding site elements and cooperation with the p107 gene product. Oncogene 23:1088-1097. CrossRef Medline

Maiti B, Li J, de Bruin A, Gordon F, Timmers C, Opavsky R, Patil K, Tuttle J, Cleghorn W, Leone G (2005) Cloning and characterization of mouse E2F8, a novel mammalian E2F family member capable of blocking cellular proliferation. J Biol Chem 280:18211-18220. CrossRef Medline

Malynn BA, de Alboran IM, O'Hagan RC, Bronson R, Davidson L, DePinho RA, Alt FW (2000) N-myc can functionally replace c-myc in murine development, cellular growth, and differentiation. Genes Dev 14:13901399. Medline

Maris JM (2010) Recent advances in neuroblastoma. N Engl J Med 362: 2202-2211. CrossRef Medline

Marshall CJ (1995) Specificity of receptor tyrosine kinase signaling: transient versus sustained extracellular signal-regulated kinase activation. Cell 80:179-185. CrossRef Medline

Martins RA, Zindy F, Donovan S, Zhang J, Pounds S, Wey A, Knoepfler PS, Eisenman RN, Roussel MF, Dyer MA (2008) N-myc coordinates retinal growth with eye size during mouse development. Genes Dev 22:179-193. CrossRef Medline

Mazot P, Cazes A, Boutterin MC, Figueiredo A, Raynal V, Combaret V, Hallberg B, Palmer RH, Delattre O, Janoueix-Lerosey I, Vigny M (2011) The constitutive activity of the ALK mutated at positions F1174 or R1275 impairs receptor trafficking. Oncogene 30:2017-2025. CrossRef Medline

Mosse YP, Laudenslager M, Longo L, Cole KA, Wood A, Attiyeh EF, Laquaglia MJ, Sennett R, Lynch JE, Perri P, Laureys G, Speleman F, Kim C, Hou C, Hakonarson H, Torkamani A, Schork NJ, Brodeur GM, Tonini GP, Rappaport E, et al. (2008) Identification of ALK as a major familial neuroblastoma predisposition gene. Nature 455:930-935. CrossRef Medline

Nagy K, Sung HK, Zhang P, Laflamme S, Vincent P, Agha-Mohammadi S, Woltjen K, Monetti C, Michael IP, Smith LC, Nagy A (2011) Induced pluripotent stem cell lines derived from equine fibroblasts. Stem Cell Rev 7:693-702. CrossRef Medline

Nakayama K, Nagahama H, Minamishima YA, Miyake S, Ishida N, Hatakeyama S, Kitagawa M, Iemura S, Natsume T, Nakayama KI (2004) Skp2-mediated degradation of p27 regulates progression into mitosis. Dev Cell 6:661-672. CrossRef Medline

Nikoletopoulou V, Lickert H, Frade JM, Rencurel C, Giallonardo P, Zhang L, Bibel M, Barde YA (2010) Neurotrophin receptors TrkA and TrkC cause neuronal death whereas TrkB does not. Nature 467:59-63. CrossRef Medline

Otto T, Horn S, Brockmann M, Eilers U, Schüttrumpf L, Popov N, Kenney AM, Schulte JH, Beijersbergen R, Christiansen H, Berwanger B, Eilers M (2009) Stabilization of N-Myc is a critical function of Aurora A in human neuroblastoma. Cancer Cell 15:67-78. CrossRef Medline

Park SA, Platt J, Lee JW, Lopez-Giraldez F, Herbst RS, Koo JS (2015) E2F8 as a novel therapeutic target for lung cancer. J Natl Cancer Inst 107:pii: djr151. CrossRef Medline

Penn LJ, Brooks MW, Laufer EM, Land H (1990) Negative autoregulation of c-myc transcription. The EMBO J 9:1113-1121. Medline

Pfaffl MW, Horgan GW, Dempfle L (2002) Relative expression software tool (REST) for group-wise comparison and statistical analysis of relative expression results in real-time PCR. Nucleic Acids Res 30:e36. CrossRef Medline

Potzner MR, Tsarovina K, Binder E, Penzo-Méndez A, Lefebvre V, Rohrer H, Wegner M, Sock E (2010) Sequential requirement of Sox4 and Sox11 during development of the sympathetic nervous system. Development 137:775-784. CrossRef Medline

Puissant A, Frumm SM, Alexe G, Bassil CF, Qi J, Chanthery YH, Nekritz EA, Zeid R, Gustafson WC, Greninger P, Garnett MJ, McDermott U, Benes CH, Kung AL, Weiss WA, Bradner JE, Stegmaier K (2013) Targeting MYCN in neuroblastoma by BET bromodomain inhibition. Cancer Discov 3:308-323. CrossRef Medline

Reiff T, Tsarovina K, Majdazari A, Schmidt M, del Pino I, Rohrer H (2010) Neuroblastoma phox $2 \mathrm{~b}$ variants stimulate proliferation and dedifferentiation of immature sympathetic neurons. J Neurosci 30:905-915. CrossRef Medline

Reiff T, Huber L, Kramer M, Delattre O, Janoueix-Lerosey I, Rohrer H (2011) Midkine and Alk signaling in sympathetic neuron proliferation and neuroblastoma predisposition. Development 138:4699-4708. CrossRef Medline

Ribeiro D, Klarqvist MD, Westermark UK, Oliynyk G, Dzieran J, Kock A, Savatier Banares C, Hertwig F, Johnsen JI, Fischer M, Kogner P, Lovén J, Arsenian Henriksson M (2016) Regulation of nuclear hormone receptors by MYCN-driven miRNAs impacts neural differentiation and survival in neuroblastoma patients. Cell Rep 16:979-993. CrossRef Medline

Rohrer H (2011) Transcriptional control of differentiation and neurogenesis in autonomic ganglia. Eur J Neurosci 34:1563-1573. CrossRef Medline

Rohrer H, Thoenen H (1987) Relationship between differentiation and terminal mitosis: chick sensory and ciliary neurons differentiate after termi- 
nal mitosis of precursor cells whereas sympathetic neurons continue to divide after differentiation. J Neurosci 7:3739-3748. Medline

Rohrer H, Acheson AL, Thibault J, Thoenen H (1986) Developmental potential of quail dorsal root ganglion cells analyzed in vitro and in vivo. J Neurosci 6:2616-2624. Medline

Sawai S, Shimono A, Wakamatsu Y, Palmes C, Hanaoka K, Kondoh H (1993) Defects of embryonic organogenesis resulting from targeted disruption of the N-myc gene in the mouse. Development 117:1445-1455. Medline

Schlessinger J, Bar-Sagi D (1994) Activation of Ras and other signaling pathways by receptor tyrosine kinases. Cold Spring Harb Symp Quant Biol 59:173-179. CrossRef Medline

Simon T, Berthold F, Borkhardt A, Kremens B, De Carolis B, Hero B (2011) Treatment and outcomes of patients with relapsed, high-risk neuroblastoma: results of German trials. Pediatr Blood Cancer 56:578-583. CrossRef Medline

Stanton BR, Perkins AS, Tessarollo L, Sassoon DA, Parada LF (1992) Loss of $\mathrm{N}$-myc function results in embryonic lethality and failure of the epithelial component of the embryo to develop. Genes Dev 6:2235-2247. CrossRef Medline

Sutterlüty H, Chatelain E, Marti A, Wirbelauer C, Senften M, Müller U, Krek $\mathrm{W}$ (1999) p45SKP2 promotes $\mathrm{p} 27 \mathrm{Kip} 1$ degradation and induces $\mathrm{S}$ phase in quiescent cells. Nat Cell Biol 1:207-214. CrossRef Medline

Valentijn LJ, Koster J, Haneveld F, Aissa RA, van Sluis P, Broekmans ME, Molenaar JJ, van Nes J, Versteeg R (2012) Functional MYCN signature predicts outcome of neuroblastoma irrespective of MYCN amplification. Proc Natl Acad Sci U S A 109:19190-19195. CrossRef Medline

Weiss WA, Aldape K, Mohapatra G, Feuerstein BG, Bishop JM (1997) Targeted expression of MYCN causes neuroblastoma in transgenic mice. EMBO J 16:2985-2995. CrossRef Medline

Westermann F, Henrich KO, Wei JS, Lutz W, Fischer M, König R, Wiede- meyer R, Ehemann V, Brors B, Ernestus K, Leuschner I, Benner A, Khan J, Schwab M (2007) High Skp2 expression characterizes high-risk neuroblastomas independent of MYCN status. Clin Cancer Res 13:4695-4703. CrossRef Medline

Westermann F, Muth D, Benner A, Bauer T, Henrich KO, Oberthuer A, Brors B, Beissbarth T, Vandesompele J, Pattyn F, Hero B, König R, Fischer M, Schwab M (2008) Distinct transcriptional MYCN/c-MYC activities are associated with spontaneous regression or malignant progression in neuroblastomas. Genome Biol 9:R150. CrossRef Medline

Whyte WA, Orlando DA, Hnisz D, Abraham BJ, Lin CY, Kagey MH, Rahl PB, Lee TI, Young RA (2013) Master transcription factors and mediator establish super-enhancers at key cell identity genes. Cell 153:307319. CrossRef Medline

Woodard LE, Wilson MH (2015) piggyBac-ing models and new therapeutic strategies. Trends Biotech 33:525-533. CrossRef Medline

Wu L, Grigoryan AV, Li Y, Hao B, Pagano M, Cardozo TJ (2012) Specific small molecule inhibitors of Skp2-mediated p27 degradation. Chem Biol 19:1515-1524. CrossRef Medline

Zackenfels K, Oppenheim RW, Rohrer H (1995) Evidence for an important role of IGF-I and IGF-II for the early development of chick sympathetic neurons. Neuron 14:731-741. CrossRef Medline

Zhu S, Lee JS, Guo F, Shin J, Perez-Atayde AR, Kutok JL, Rodig SJ, Neuberg DS, Helman D, Feng H, Stewart RA, Wang W, George RE, Kanki JP, Look AT (2012) Activated ALK collaborates with MYCN in neuroblastoma pathogenesis. Cancer Cell 21:362-373. CrossRef Medline

Zinin N, Adameyko I, Wilhelm M, Fritz N, Uhlén P, Ernfors P, Henriksson MA (2014) MYC proteins promote neuronal differentiation by controlling the mode of progenitor cell division. EMBO Rep 15:383-391. CrossRef Medline 